Recreation Management Support Program

\title{
Economic Impacts from Spending by Marina Slip Renters at Harry S. Truman Dam and Reservoir
}

Dennis B. Propst, Benoni L. Amsden, Wen-Huei Chang,

February 2008

Richard Kasul, LiChu Lee, and Kathleen Perales 


\section{Economic Impacts from Spending by Marina Slip Renters at Harry S. Truman Dam and Reservoir}

Dennis B. Propst and Benoni L. Amsden

Michigan State University

115 Natural Resources Building

East Lansing, MI 48824

Wen-Huei Chang, Richard Kasul, LiChu Lee, and Kathleen Perales

Environmental Laboratory

U.S. Army Engineer Research and Development Center

3909 Halls Ferry Road

Vicksburg, MS 39180-6199

Final report

Approved for public release; distribution is unlimited.

Prepared for U.S. Army Corps of Engineers

Washington, DC 20314-1000 


\begin{abstract}
This report documents the local economic impacts of marina slip users at Harry S. Truman Dam and Reservoir, located in west-central Missouri. This economic assessment is based on the results of a 1999 survey of a sample of Harry S. Truman Dam and Reservoir marina slip renters. Spending estimates are adjusted to 2004 dollars. The economic impacts estimated for Harry S. Truman Dam and Reservoir are useful for accountability purposes, lake support, and explaining the role of the lake in the region's economy. This report demonstrates how the survey results can also be used to evaluate management alternatives and strategies and to conduct sensitivity analyses.
\end{abstract}

DISCLAIMER: The contents of this report are not to be used for advertising, publication, or promotional purposes. Citation of trade names does not constitute an official endorsement or approval of the use of such commercial products. All product names and trademarks cited are the property of their respective owners. The findings of this report are not to be construed as an official Department of the Army position unless so designated by other authorized documents. 


\section{Contents}

Figures and Tables................................................................................................................

Summary

Foreword .....................................................................................................................................................viii

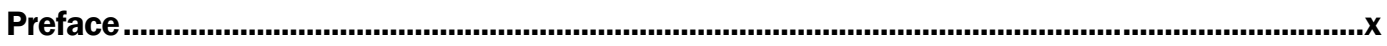

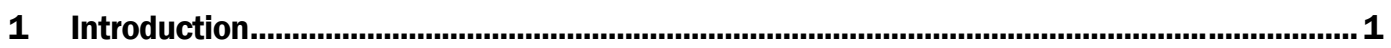

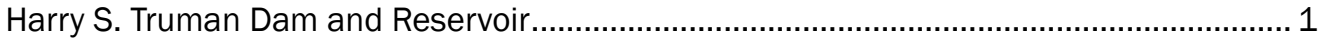

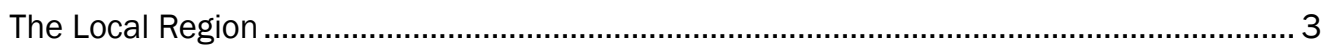

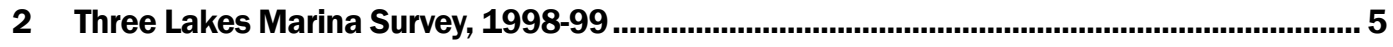

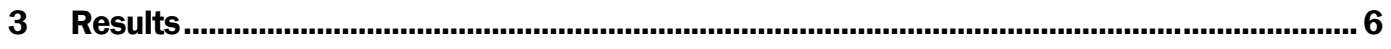

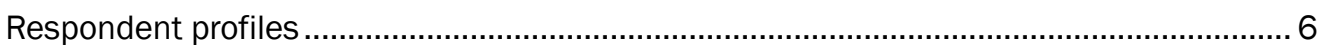

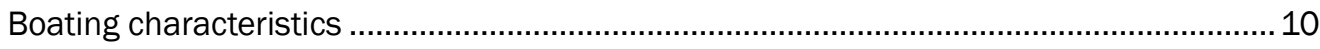

Activities while boating ..............................................................................................11

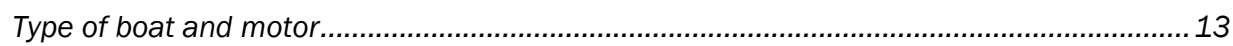

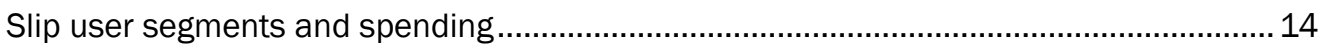

Average spending for full sample of slip renters........................................................ 14

Average spending by segment: Day use vs. overnight................................................... 16

Average spending by boat length segments.................................................................... 18

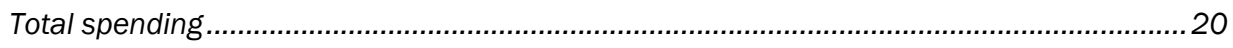

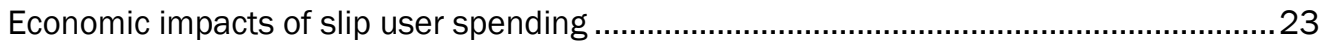

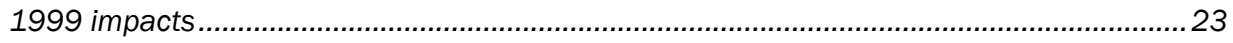

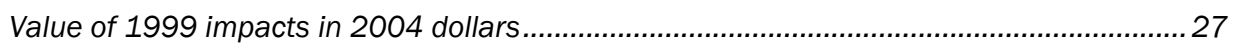

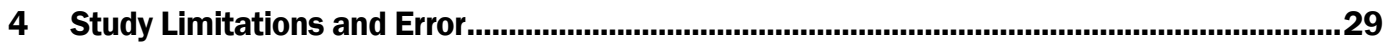

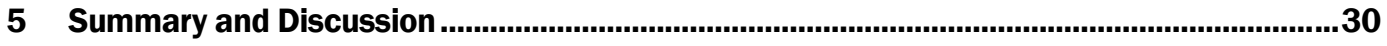

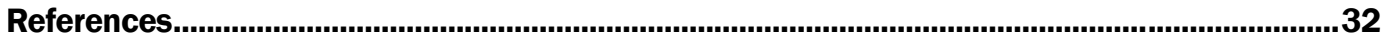

\section{Report Documentation Page}




\section{Figures and Tables}

\section{Figures}

Figure 1. Harry S. Truman Lake and the surrounding region. 2

Figure 2. Gender of marina slip renters at Truman Lake, $1999(\mathrm{~N}=202)$......................................... 6

Figure 3. Age of marina slip renters at Truman Lake, $1999(\mathrm{~N}=200)$............................................ 7

Figure 4. Education of marina slip renters at Truman Lake, 1999 (N=198).................................... 7

Figure 5. Race of marina slip renters at Truman Lake, 1999 ( $N=197)$ (about 0.5 percent were Hispanic or of Latino origin). ............................................................................................

Figure 6. Survey conducted with registered boat owners at Truman Lake Marina, 1999 $(\mathrm{N}=202)$.

Figure 7. Household income of marina slip renters at Truman Lake, $1999(\mathrm{~N}=180)$....................... 8

Figure 8. Household size of marina slip renters at Truman Lake, 1999 ( $\mathrm{N=202})$............................ 9

Figure 9. Number of people under 18 in households of marina slip renters at Truman

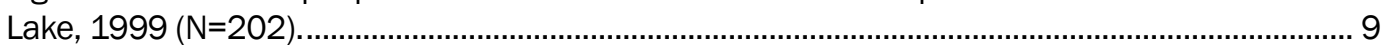

Figure 10. Permanent residence of marina slip renters at Truman Lake, $1999(\mathrm{~N}=201)$............... 10

Figure 11. Seasonal home ownership of marina slip renters at Truman Lake, 1999 $(\mathrm{N}=202)$.

Figure 12. Number of boating trips made by marina slip renters last year compared to previous 3-year average at Truman Lake, $1999(\mathrm{~N}=184)$.

Figure 13. What other activities did you or others participate in during your boating trips last year that I have not already mentioned?" (from Truman Lake Marina, 1999, N=192).

Figure 14. Expenditures by marina slip renters/users on most recent trip compared to similar trips in the last 12 months at Truman Lake, 1999 ( $N=197)$.

\section{Tables}

Table 1. Summary of recreation visits to Harry S. Truman Dam and Reservoir, 1999...................... 3

Table 2. Economic activity in the Harry S. Truman Dam and Reservoir region, 2000.

Table 3. Number of boating trips to Truman Lake Marina the previous year (09/01/1998 to $08 / 31 / 1999$ ).

Table 4. Recreation activity participation during previous year's boating trips to Truman Lake Marina (09/01/1998 to 08/31/1999)

Table 5. Boat type and length cross-tabulation, Truman Lake Marina slip renter survey, $1999(\mathrm{~N}=202)$.

Table 6. Boat type and motor cross-tabulation, Truman Lake Marina slip renter survey, $1999(N=201)$.

Table 7. Boat length and motor cross-tabulation, Truman Lake Marina slip renter survey, $1999(\mathrm{~N}=201)$.

Table 8. Summary of Truman Lake Marina slip renters'/users' spending and use profiles, 09/1998 to 08/1999 (spending per party trip). 
Table 9. Spending and use by length of stay segments, Truman Lake Marina slip renter survey, 09/1998 to 08/1999 (spending per party trip).

Table 10. Spending and use by boat length segments, Truman Lake Marina slip renter survey, 09/1998 to 08/1999 (spending per party trip).

Table 11. Total annual use figures for marina slip renter survey at Truman Lake (1999).

Table 12. Total trip spending in local area by Truman Lake Marina slip renters/users (1999).

Table 13. Total trip spending by Truman Lake Marina slip renters/users (1999).

Table 14. Total spending on fixed, annual goods and services by marina slip renters at Truman Lake (1999).

Table 15. Regional economic impacts of Truman Lake Marina slip renters'/users' trip spending (1999, for trip spending within 30 miles only).

Table 16. Regional economic impacts of Truman Lake Marina slip renters' durable goods and annual spending (1999).

Table 17. Regional economic impacts of Truman Lake Marina slip renters'/users' trip and renters' annual spending (in 2004 dollars, for spending within 30 miles only).

Table 18. Direct impacts of an additional 1,000 marina slip renter party trips by segment, Truman Lake. 


\section{Summary}

This report documents the local economic impacts of marina slip renters and guests at Harry S. Truman Dam and Reservoir, located in west-central Missouri and situated within the U.S. Army Corps of Engineers District, Kansas City. This economic assessment is based on the results of a 1999 survey of a sample of Harry S. Truman Dam and Reservoir (Truman Lake) marina slip renters. Spending estimates are adjusted to 2004 dollars.

With its centralized location-an hour and a half drive from either Kansas City or Springfield-and its large size, Truman Lake attracts significant numbers of visitors. It encompasses nearly 56,000 surface acres and boasts 110,000 acres of public land surrounding the lake. Truman Lake is the largest flood control lake in Missouri. Total tourism activity in the four-county region surrounding Truman Lake is $\$ 161$ million, or 2.3 percent of all economic activity in that region.

Its numerous developed recreation facilities and scenery make Truman Lake highly desirable for boating and the associated need for marinas in which to dock and store boats of various sizes. The Corps of Engineers tallied over 1,000 marina slips at five marinas at Truman Lake in 1999. The estimated 24,659 party trips taken by marina slip renters/users in 1999 accounted for 4.6 percent of the total recreation usage at the lake.

In 1999, marina slip renters/users spent significant amounts of money in the local region, including $\$ 3.8$ million on trip-related items (gasoline, meals, lodging, etc.) and \$1.2 million on new boats, slip rental fees, insurance, and other annual services. Together, this $\$ 5.0$ million in spending generated $\$ 3.3$ million in direct sales, $\$ 0.9$ million in direct personal income (wages and salaries) for local residents and 65 jobs in area tourismrelated businesses. The $\$ 3.3$ million in direct sales is about 2 percent of the total of all tourism activity ( $\$ 161$ million) (sales have been price inflated for this computation). In 2004 dollars, these figures become $\$ 4.6$ million in trip-related expenditures and $\$ 1.4$ million in new boats and annual expenses. The added economic effects-in 2004 dollars-are \$4 million in direct sales and $\$ 1.1$ million in direct personal income. 
The above figures are direct effects only of the $\$ 5.0$ million in slip renter/user spending in 1999. Another \$1.4 million in sales ( $\$ 1.7$ million in 2004 dollars) is generated through secondary effects, as slip renter/user spending circulates through the local economy. While the direct effects accrue primarily to the retail trade sector, restaurants, manufacturing (mainly because of the purchases of new boats locally), and services, secondary effects benefit a wide range of local businesses. The tourism sales multiplier for the region is 1.45 , indicating there is $\$ 0.45$ in secondary sales for every dollar of direct sales.

Visitor segmentation is useful for planning purposes. This report provides results for the full sample of marina slip renters/users and for slip renter segments that are useful for planning purposes: day use vs. overnight stay slip renters, and slip renters in three boat size classes. Day use and overnight stay segments were almost evenly split in the sample. Day users comprised 53 percent of the sample of marina slip users, while 47 percent spent a least one night in the area on their last trip. In terms of total spending in the local region, day users of marina slips contributed 30 percent, and overnight stay slip users, 70 percent. Half the sample had medium-sized boats ( 21 to $30 \mathrm{ft}$ ), while the other half were small (under $21 \mathrm{ft}$ ) and a small percentage were large (above $30 \mathrm{ft}$ ). Slip users with large boats contributed 7 percent of total spending locally, slip users with mediumsized boats, 48 percent, and those with small boats, 45 percent.

The economic impacts estimated for Truman Lake are useful for accountability purposes, lake support, and explaining the role of the lake in the region's economy. This report demonstrates how the survey results can also be used to evaluate management alternatives and strategies and to conduct sensitivity analyses. 


\section{Foreword}

This report represents one of nine market segmentation studies conducted at Corps of Engineers (Corps) water resources projects (lakes). The economic impact studies were conducted in 1999 and the information has been converted to 2004 dollars. It should be noted that no single study provides a complete portrait of any lake's boating market. The studies were limited to three market segments: marina slip renters, private dock, and community dock owners. These three groups do not reflect the spectrum of boating usage or market segments at any one of the lakes studied. The primary purpose of the studies was to obtain an understanding of these three market segments.

In addition to recreation usage, each of these segments is handled under different real estate instruments or shoreline use permit instruments. Marina slips (one boat per slip) are handled by the Corps at the marina facility level. Individual marina operators (lease holders) were involved in the development of contact lists for individual slip renters. Private dock owners (one dock permit, one household, potentially multiple boats) have a direct shoreline-use permit with the Corps and pay a fee. Community docks (one dock permit, multiple households, one boat per slip, a single household may hold multiple slips) are not tied to a single household but to a group of homes within a community. This permit type has a single point of contact (e.g. homeowner association). Typically the fee for a private or community dock permit is between $\$ 30$ and $\$ 35$ for 5 years. Additional administrative fees may also be collected to recover the cost of administration inspections and processing of permits; the cost is variable.

The lakes and market segments studied were:

- Table Rock Lake, community dock

- Rough River Lake, community dock

- Pomme de Terre Lake, community dock

- Harry S. Truman Dam and Reservoir, marina

- Raystown Lake, marina

- Hartwell Lake, private dock

- Lake Barkley, private dock

- Lake Sidney Lanier, private dock and marina 
Each of the lakes studied has a variety of boating and water usage issues that were not a part of this economic impact evaluation. This economic impact assessed recreation visitor trip spending and annual durable goods-related expenditures. In order to provide managers with a tool to assess the effects of management, this report outlined the spending categories of boat owners and visitors associated with the recreational trip under study. Examples are provided illustrating changes in the number of boat trips and the changes that could be seen in economic impacts. These are provided as illustrations. The same illustration can be used by managers to help assess low water conditions and boating trips lost, to get a sense of the change in economic impacts. This study did not include the impacts of additional boats over time to determine changes in use, water quality, social or environmental impacts, or the like. This study did not include changes in use based on increases in gasoline prices or technological changes in boating products. These are elements outside the study parameters and would serve as useful points of departure for further research. These reports should be evaluated in part with the larger boating usage that occurs at the individual lake and the changes that have occurred over time (including expenditure changes such as the increasing cost of gasoline). They serve in part to document a baseline, which in part justifies publication at this late date.

For example, at a single lake, boating utilization should be evaluated within a larger context of the multipurpose mission of each of the lakes. To get an understanding of historical use and issues at Corps of Engineers facilities, the following documents have been recommended for further study: national and state regulations, project master-planning documents, shoreline management plans, environmental assessments, and other local studies. Consult the local project manager for an assessment of other documents that should be considered in addition to the ones provided. 


\section{Preface}

The work reported herein was undertaken for the "Measuring the Economic Effects of Boat Dock Permit and Marina Slip Holders" work unit of the Recreation Management Support Program (RMSP). The RMSP is funded by the Operations and Maintenance (O\&M) General Appropriation and encompasses activities previously conducted through the Recreation Research Program and the Natural Resources Technical Support Program. The U.S. Army Engineer Research and Development Center (ERDC) provides program management support for execution of approved RMSP activities. The RMSP is managed at ERDC by Scott Jackson, Environmental Laboratory (EL). Kathleen Perales has served as Principal Investigator of the work unit since its creation in 1995.

This report documents a joint effort between ERDC and Michigan State University under contract with the United States Department of Agriculture to conduct lake level investigations on the economic spending patterns of visitors to communities, private boat docks, and marinas on Corps of Engineers water resources projects.

A Recreation Leadership Advisory Team (RLAT) provides oversight for the RMSP. The team has representatives from each Major Subordinate Command/Regional Office within the Corps of Engineers. In addition, four district offices and four project offices are represented. Donald Dunwoody, RLAT representative from the Northwestern Division, served as proponent for this work unit.

This report was prepared by Benoni Amsden and Dr. Dennis Propst of Michigan State University under USDA contract. Dr. Wen-Huei Chang, ERDC, performed all economic impact analyses. Dr. LiChu Lee, ERDC, served to verify all data elements. Richard Kasul, ERDC, and Kathleen Perales, ERDC, were responsible for the design, instrumentation, sampling frame, and contract oversight. This work was conducted under the general supervision of Scott Jackson, Acting Chief, Ecological Resources Branch (ERB); Dr. David Tazik, Chief, Ecosystem Evaluation and Engineering Division (EEED); and Dr. Beth Fleming, Director, EL. 
Peer reviewers of this report were Tammy Gilmore, Natural Resource Manager, Harry S. Truman Dam and Reservoir, USACE; and Robert A. Marchi, Operations Project Manager, Harry S. Truman Dam and Reservoir, USACE.

COL Richard B. Jenkins was Commander and Executive Director of ERDC. Dr. James R. Houston was Director. 


\section{Introduction}

This report documents the local economic impacts of marina slip users at Truman Lake, located in west-central Missouri. These estimates are then adjusted to 2004 dollars. Economic impacts are measured as the direct and secondary sales, income, and jobs in the local area resulting from spending by those who use marina slips. The economic estimates are produced using the Recreation Economic Assessment System (REAS) (Chang et al. 2001). Three major inputs to the model are:

- number of visits broken down into day use/overnight segments and three boat size segments

- spending averages for each segment

- economic multipliers for the local region

Inputs are derived from results contained in this report, the Natural Resource Management System (NRMS) database (U.S. Army Corps of Engineers (USACE) 2006c), and IMPLAN input-output modeling software (Minnesota IMPLAN Group 1996). The REAS model (USACE 2006a) provides a spreadsheet template for combining marina slip user visitation data, spending and regional multipliers to compute changes in sales, personal income, jobs, and value added in the region.

\section{Harry S. Truman Dam and Reservoir}

The Army Corps of Engineers manages this 259-square-mile project located in portions of four Missouri counties: Benton, Henry, Hickory, and St. Clair (Figure 1). The main attraction is the lake itself, which is the largest flood control lake in Missouri. It encompasses nearly 56,000 surface acres and boasts 110,000 acres of public land surrounding the lake. Authorized in 1954 as the Kaysinger Bluff Dam and Reservoir, the project was renamed in 1970 and completed in 1979. With five full-service marinas, 12 campgrounds, and a centralized location between Kansas City and Springfield, Truman Lake (USACE 2006b) attracts significant numbers of visitors to the local region. 


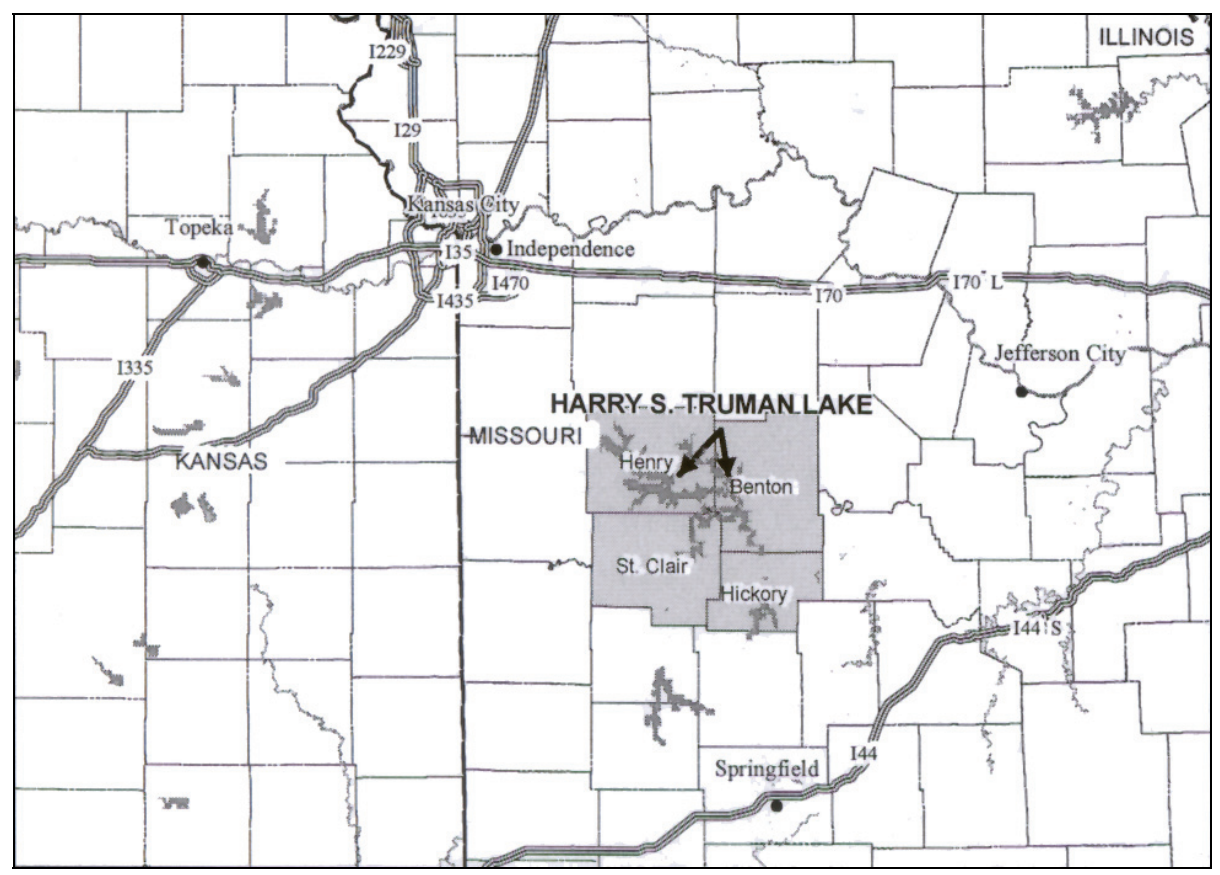

Figure 1. Harry S. Truman Lake and the surrounding region.

The project also includes 14 group picnic shelters and 7 sand swimming beaches. In addition, visitors enjoy hunting, fishing, and an off-road vehicle area. Interpretive facilities include a unique visitor center, and historical artifacts such as the Hooper House and White Oak Cabin.

Truman Lake hosted nearly 1.6 million recreation visits in 1999, 95 percent of which were by day users (Table 1, top row). Boaters accounted for 972,000 total day use visits, and non-boaters another 547,000. Since visitor spending and economic impacts in this report are based on party-days or nights, these figures are shown on the bottom row of Table 1. In 1999, there were roughly 636,000 party-days of recreation use. 
Table 1. Summary of recreation visits to Harry S. Truman Dam and Reservoir, 1999.

\begin{tabular}{|c|c|c|c|c|c|c|c|}
\hline & \multicolumn{2}{|c|}{ Camper ${ }^{1}$} & \multicolumn{2}{|c|}{ Day User² } & \multicolumn{2}{|c|}{ Other Overnight ${ }^{3}$} & \multirow[b]{2}{*}{ Total } \\
\hline & Boat & Non-Boat & Boat & Non-Boat & Boat & Non-Boat & \\
\hline Visits (Person-Trips, 1000s) & 24.4 & 13.7 & 971.6 & 546.5 & 29.1 & 16.4 & $1,601.9$ \\
\hline Average Length of Stay (Days) & 4.2 & 3.8 & - & - & 2.4 & 3.0 & - \\
\hline Average Party Size & 3.5 & 2.8 & 2.8 & 2.8 & 3.3 & 2.5 & - \\
\hline Visits (Party-Days, 1000s) & 29.4 & 19.0 & 349.0 & 197.5 & 21.6 & 19.9 & 636.4 \\
\hline \multicolumn{8}{|c|}{$\begin{array}{l}1 \text { Number of campers in party days was derived from the } 1998 \text { NRMS (USACE 2006c), CUR_FEE database (the last year that } \\
\text { camper revenue data is available) by dividing total camping revenue by an average of } \$ 8.00 \text { per party day camping fee and } \\
\text { expanding by the number of non-Corps managed campsites. The number of camper party-days was then adjusted to } 1999 \text { by } \\
\text { multiplying the ratio of } 1999 \text { visits to } 1998 \text { visits from the PR_USE database. Then, party-days were converted to person-trips by } \\
\text { the following formula: Number of campers in person-trips = number of party-days times average party size/average length of } \\
\text { stay. Percent of boaters was obtained from the NRMS, PR_USE database. Party Size and Length of Stay figures are based on } \\
\text { the results of a national survey (Chang et al. 2003). }\end{array}$} \\
\hline
\end{tabular}

\section{The Local Region}

Benton, Henry, Hickory, and St. Clair counties comprise the local economic impact study region for Truman Lake. The economy of this area is growing at a rate similar to that of Missouri as a whole, with Benton and Hickory counties in the lead (Missouri Economic Research and Information Center (MERIC) 2004). According to the U.S. Census Bureau (2006), the population for the four counties is 57,769 (1999) or 59,927 (2004 estimate), with an average median household income of \$27,066 (1999). This can be compared to a Missouri population of 5,595,211 (1999) or $5,754,618$ (2004 estimate) and a median household income of $\$ 37,934$ (1999).

The Construction, Manufacturing, Other Services, FIRE (Finance, Insurance and Real Estate) and Government sectors are the principal economic base of the area, combining to account for 64 percent of sales, 60 percent of jobs, and 73 percent of compensation (wages) in the four-county region (Table 2). An estimate of total tourism sales in the local region is $\$ 161$ million (Table 2: 100 percent of hotel $/$ motel +100 percent of amusement and recreation +25 percent of restaurant +25 percent of retail sales. Thus, tourism accounts for 2-3 percent of sales in the region and 5-6 percent of 
jobs $^{1}$. In 2000, hotel sales in the four counties were $\$ 24$ million, supporting 693 jobs in the hotels and lodging sector (Minnesota IMPLAN Group 2000).

Table 2. Economic activity in the Harry S. Truman Dam and Reservoir region, 2000.

\begin{tabular}{|l|c|c|c|c|c||}
\hline \multirow{2}{*}{ Industry } & \multirow{2}{*}{$\begin{array}{c}\text { Output } \\
\text { (\$ millions) }\end{array}$} & Employment & $\begin{array}{c}\text { Compensation } \\
\text { (\$ millions) }\end{array}$ & $\begin{array}{c}\text { Value Added } \\
\text { (\$ millions) }\end{array}$ & \% Output \\
\hline \hline Agriculture, forestry, fish & 452.42 & $10,409.27$ & 26.27 & 110.74 & $7 \%$ \\
\hline Mining & 33.42 & 216.90 & 7.69 & 15.68 & $0.5 \%$ \\
\hline Construction & 669.41 & $6,571.21$ & 148.80 & 219.19 & $10 \%$ \\
\hline Food processing & 593.33 & $2,761.46$ & 78.85 & 121.08 & $9 \%$ \\
\hline Apparel & 40.97 & 436.35 & 8.52 & 10.92 & $1 \%$ \\
\hline Manufacturing & $1,190.87$ & $8,269.56$ & 264.75 & 382.90 & $17 \%$ \\
\hline Sporting goods & 23.03 & 242.97 & 4.09 & 8.47 & $0.3 \%$ \\
\hline Auto parts and access & 203.39 & 824.20 & 47.58 & 64.00 & $2.9 \%$ \\
\hline Transp. and commu. & 316.47 & $2,791.68$ & 73.19 & 138.15 & $5 \%$ \\
\hline Other services & 880.48 & $17,002.85$ & 293.53 & 499.86 & $13 \%$ \\
\hline Wholesale trade & 175.56 & $2,490.20$ & 66.98 & 119.11 & $3 \%$ \\
\hline Retail & 369.18 & $10,283.75$ & 157.45 & 295.88 & $5 \%$ \\
\hline Eating and drinking & 150.04 & $5,147.48$ & 46.00 & 68.49 & $2 \%$ \\
\hline Finance, insurance and real & & & & & $12 \%$ \\
\hline estate & 801.97 & $4,803.39$ & 83.23 & 566.29 & $12 \%$ \\
\hline Hotels and lodging places & 24.43 & 692.90 & 6.93 & 13.23 & $0.4 \%$ \\
\hline Auto services & 54.04 & 815.01 & 12.74 & 29.04 & $1 \%$ \\
\hline Other amusements & 20.09 & 522.53 & 3.43 & 5.47 & $0.3 \%$ \\
\hline Amusement and rec services & 6.59 & 287.00 & 1.87 & 3.95 & $0.1 \%$ \\
\hline Gov't and other & 915.97 & $19,114.90$ & 676.36 & 867.04 & $13 \%$ \\
\hline Total & $6,921.66$ & $93,683.62$ & $2,008.25$ & $3,539.48$ & $100 \%$ \\
\hline Source: IMPLAN, 2000 county data files for the 4-county & region. & & & \\
\hline \hline
\end{tabular}

\footnotetext{
${ }^{1}$ An independent estimate of jobs attributable to tourism in this region is 9.4 percent in 2000 (Missouri Economic Research and Information Center (MERIC). "Missouri Division of Tourist Report," Industry Studies) http://missourieconomy.org/researchandplanning/industry/index.stm (Accessed March 30, 2006).
} 


\section{Three Lakes Marina Survey, 1998-99}

The Ecological Resources Branch (ERB) of the US Army Engineer Research and Development Center (ERDC) surveyed marina slip renters at Lake Sidney Lanier (Georgia), Raystown Lake (Pennsylvania), and Harry S. Truman Dam and Reservoir (Missouri). The ERB staff designed the survey, constructed the instrument, and provided the frame (a list of marina slip renters) to the Institution for Public Policy and Social Research (IPPSR) at Michigan State University (MSU) for sampling. IPPSR obtained additional approval through MSU's Human Subjects Office. The Office of Management and Budget authorized this study (Institute for Water Resources (IWR) 2006).

Working with the project managers, the ERB contacted marina operators and obtained lists of marina slip renters. Once the contact information was received, MSU IPPSR staff sent a pre-contact mailer to the slip renters in the sample. This information packet included a description of the study and a FAQ sheet for the renter. In addition, the slip renters received a worksheet outlining the spending categories and other information regarding the upcoming telephone interview. Calls were made to slip renters in the randomly ordered sequence, until a quota of interviews was completed. In this manner, 202 randomly selected marina slip renters were interviewed at Truman Lake, representing 19 percent of the total of 1,070 eligible marina slips at the time of the survey. ${ }^{1}$

Spending and trip information were obtained through a Computer Assisted Telephone Interview (CATI) survey conducted by MSU IPPSR staff. Slip renters were asked to document the number of boating trips on the lake that originated from their marina and to report trip spending associated with their most recent trip. Spending information was collected only for the most recent trip to reduce recall bias and avoid selective recall in which renters may report spending on the most expensive trips. The telephone interview lasted an average of 15 minutes. Other information needed to estimate parameters for this population was also acquired during the interview.

${ }^{1}$ Number of marina slips derived from 1998 NRMS data. 


\section{Results}

Results are provided in four parts: respondent profiles (including socioeconomic characteristics); recreation trip characteristics (amount of boat use, recreation activities and boat type); per-trip and annual spending; and the economic impacts of slip renters'/users' spending on the local region surrounding Truman Lake.

\section{Respondent profiles}

The general characteristics of marina slip renters as individuals and by households at Truman Lake are shown in Figures 2 to 11. In general, the marina slip renters were mostly white males with high education and income. Among the respondents, 77 percent were male and nearly 88 percent were aged 46 and above (Figures 2 and 3). The average age was 58 (range $=29$ to 87 years old). Nearly 60 percent of the slip renters had at least some college education and 32 percent had college degrees or more. Ten percent of Truman's marina slip renters held graduate degrees (Figure 4). Almost all of the renters interviewed were white (Figure 5). All marina slips have registered boats; surveys may or may not have been conducted with the registered boat owner. Ninety-six percent of the renters were also the registered boat owner at the time of the interview (Figure 6).

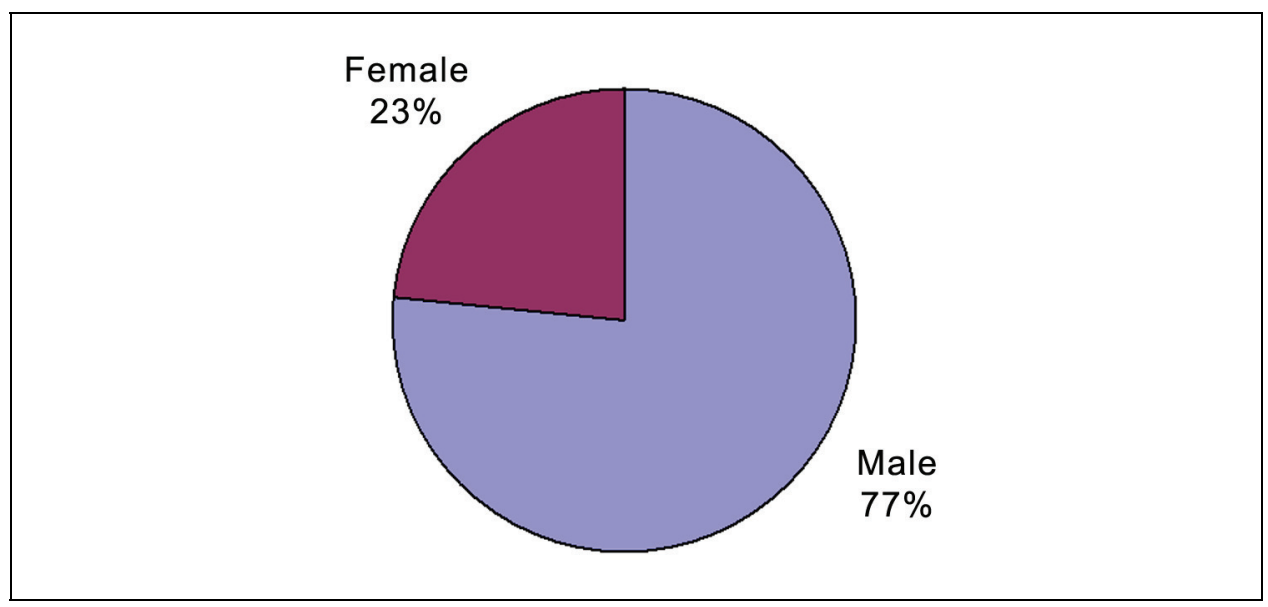

Figure 2. Gender of marina slip renters at Truman Lake, 1999 (N=202). 


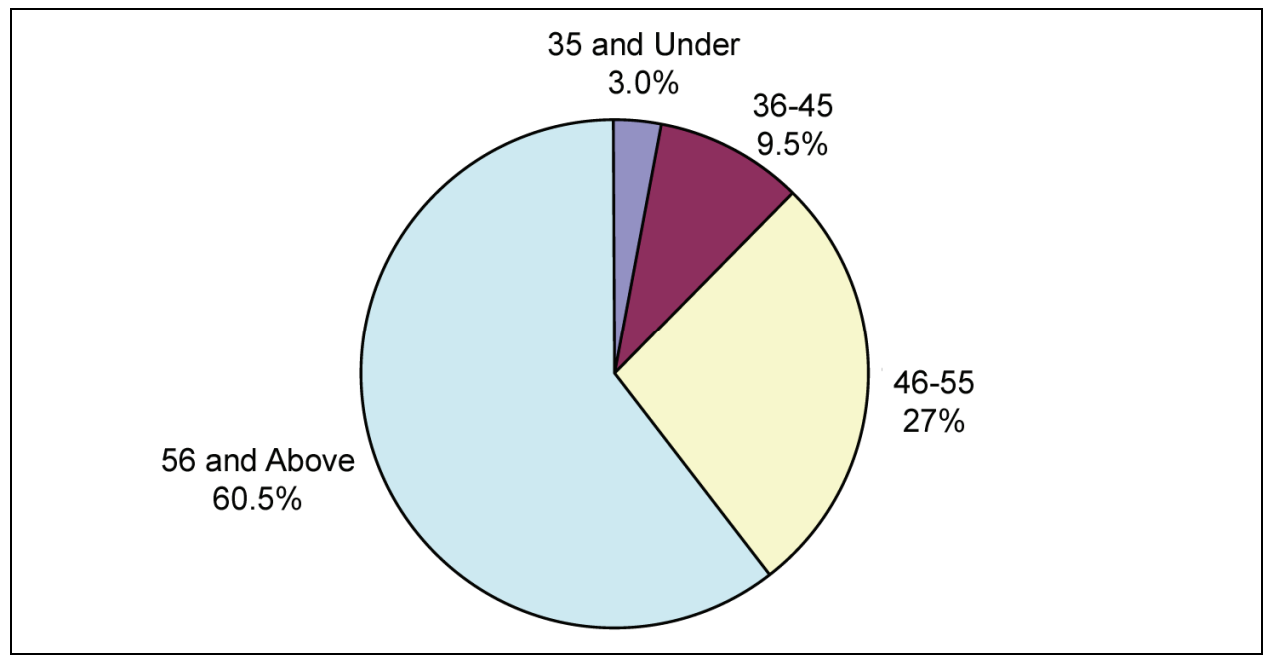

Figure 3. Age of marina slip renters at Truman Lake, $1999(\mathrm{~N}=200)$.

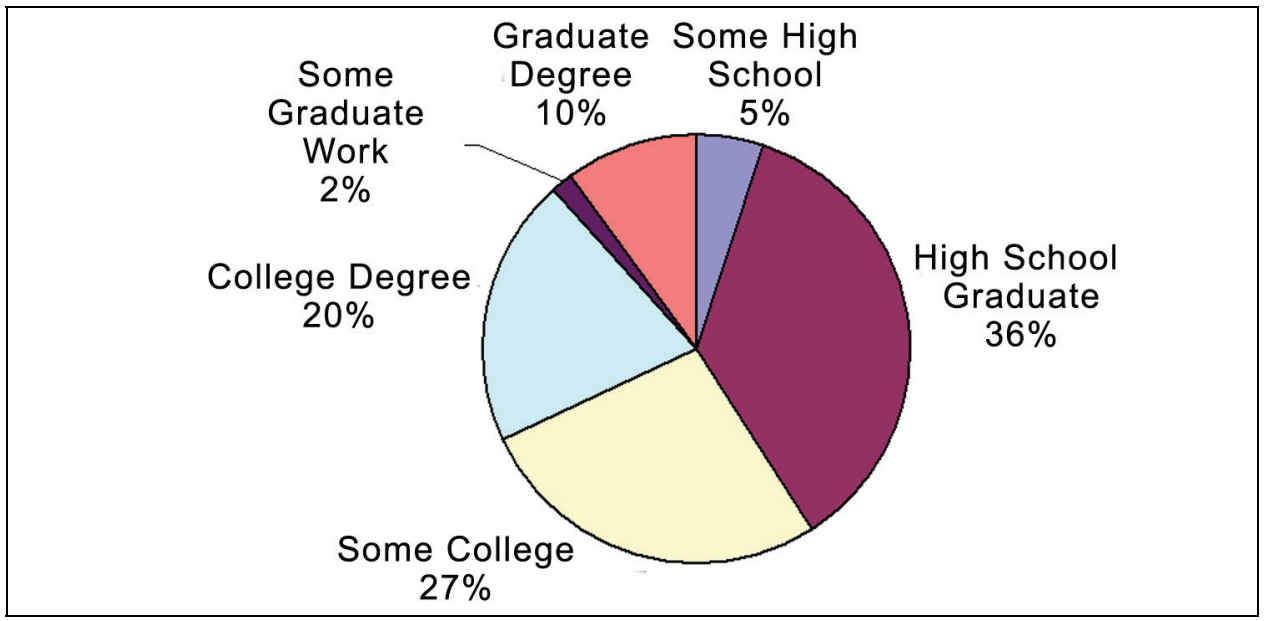

Figure 4. Education of marina slip renters at Truman Lake, $1999(\mathrm{~N}=198)$.

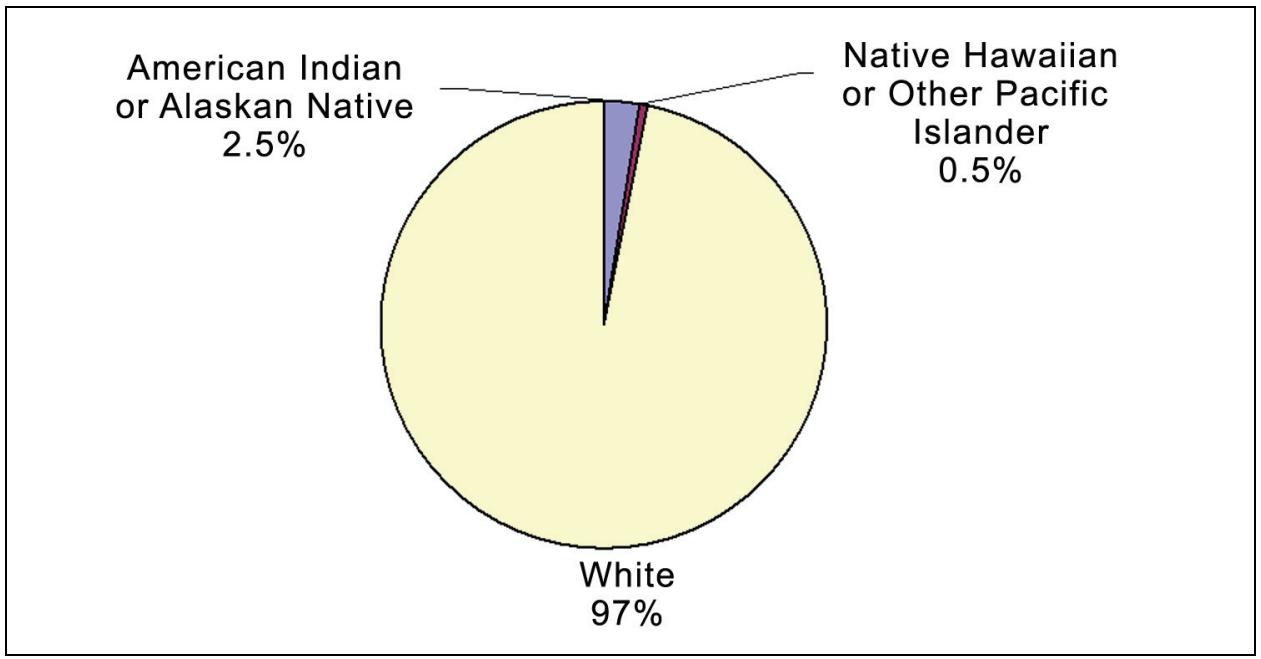

Figure 5. Race of marina slip renters at Truman Lake, $1999(\mathrm{~N}=197)$ (about 0.5 percent were Hispanic or of Latino origin). 


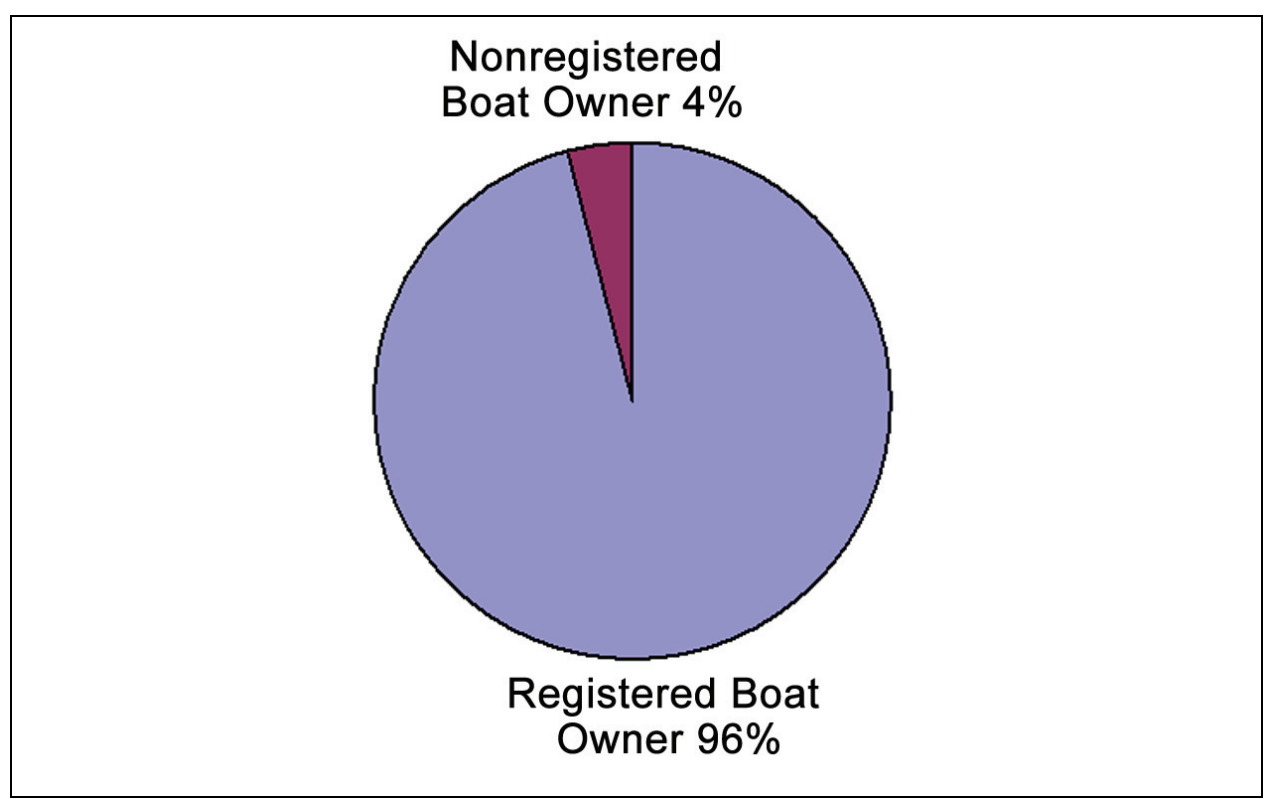

Figure 6. Survey conducted with registered boat owners at Truman Lake Marina, 1999 $(\mathrm{N}=202)$.

Many marina slip renters reported high household incomes with no or few children living in the household. Forty-four percent of the respondents had annual household incomes of at least $\$ 60,000$, with 14 percent reporting incomes of over $\$ 100,000$ (Figure 7 ). Approximately 75 percent of the renters lived in a household with two or less people and 85 percent of the renters did not have any children age under 18 in their households (Figures 8 and 9). The average number of individuals per household was 2.4. The most frequent household size (mode) was 2.

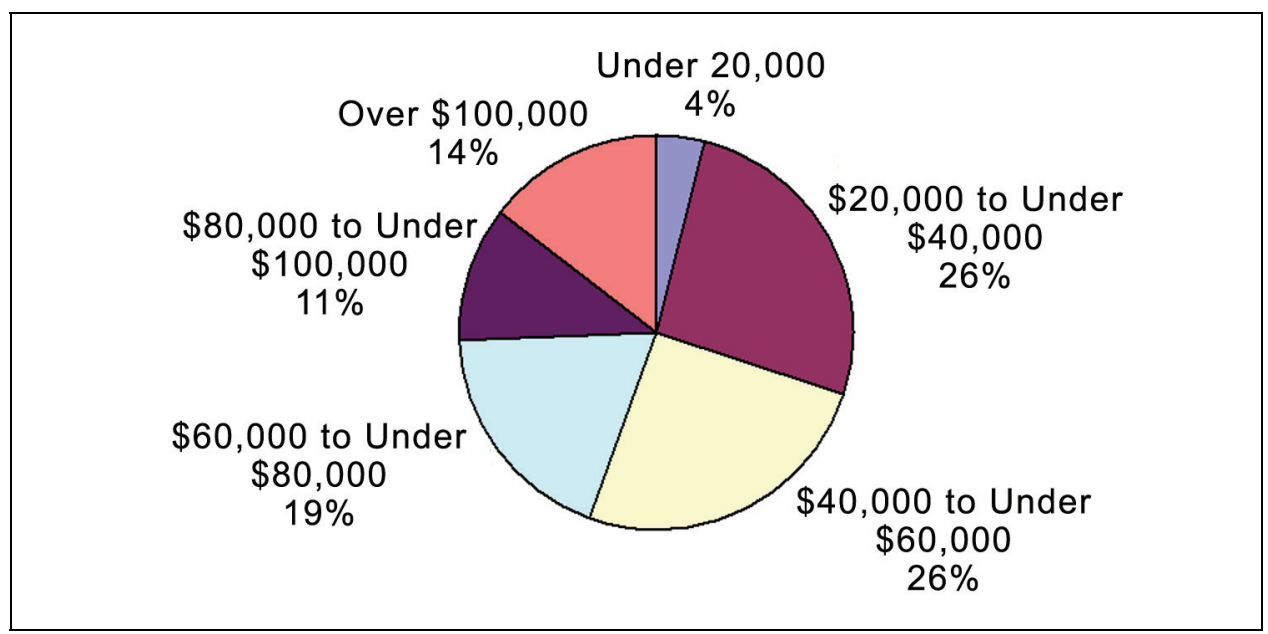

Figure 7. Household income of marina slip renters at Truman Lake, 1999 (N=180). 


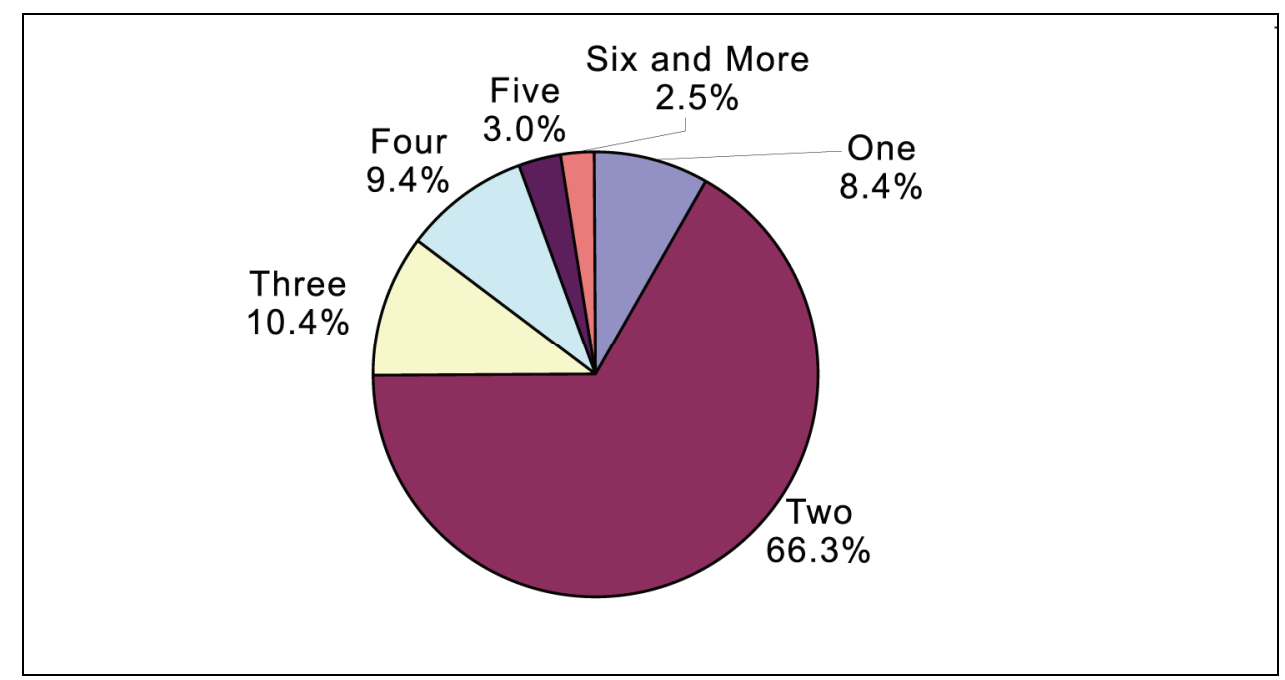

Figure 8. Household size of marina slip renters at Truman Lake, $1999(\mathrm{~N}=202)$.

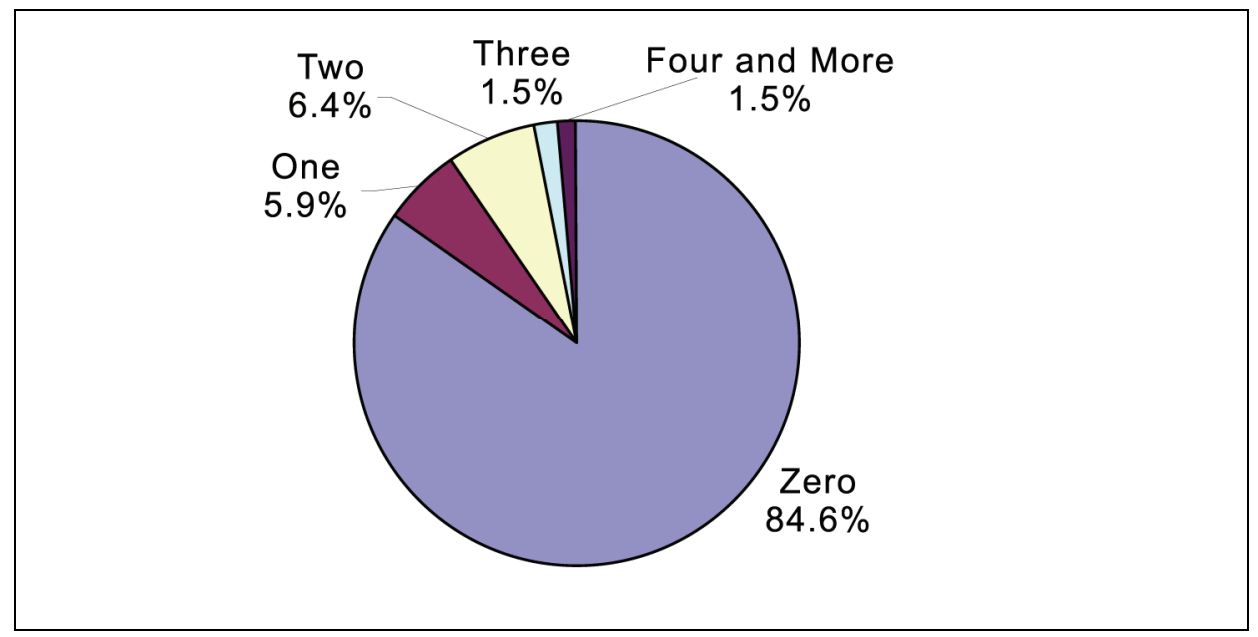

Figure 9. Number of people under 18 in households of marina slip renters at Truman Lake, 1999 ( $N=202)$.

The permanent residences of 44 percent of the renters were within 30 miles of the marina (Figure 10). The average distance from the slip renter's permanent home to the marina was 59 miles. Twenty-eight percent of the slip renters owned a seasonal home within 30 miles of the marina (Figure 11). 


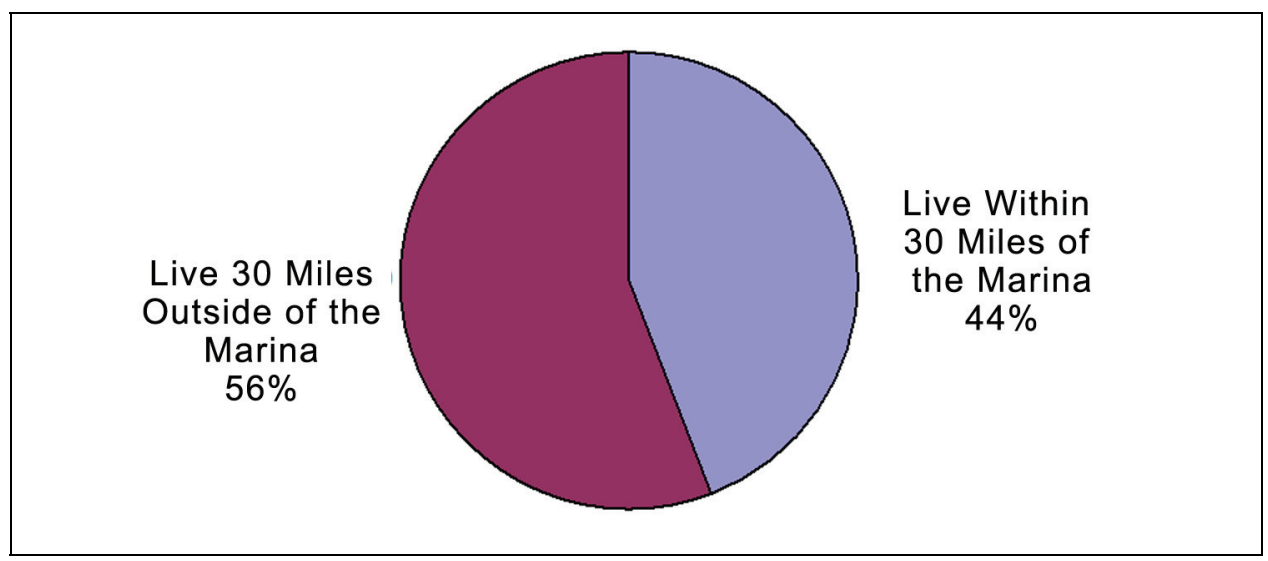

Figure 10. Permanent residence of marina slip renters at Truman Lake, 1999 ( $\mathrm{N}=201)$.

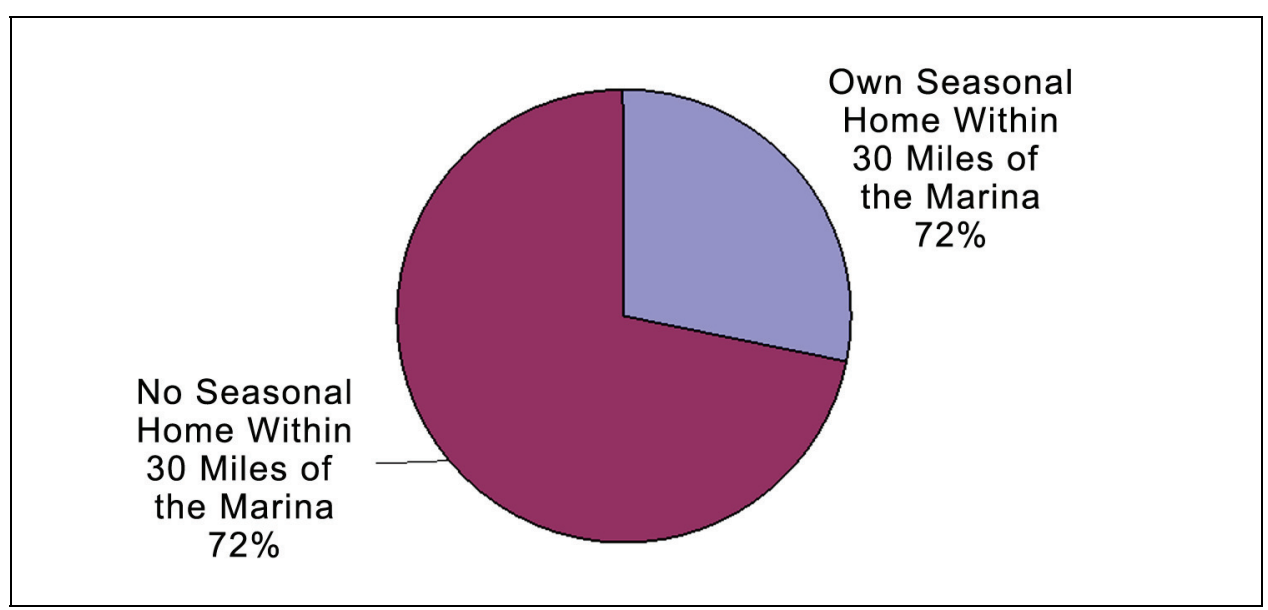

Figure 11. Seasonal home ownership of marina slip renters at Truman Lake, $1999(\mathrm{~N}=202)$.

\section{Boating characteristics}

Respondents had been boating on Truman Lake for an average of 11 years (range $=70$ years). On average, they and their quests (renters/users) took 30 boating trips the previous year from September 1, 1998 to August 31, $1999^{1}$. Half of them made 20 or less trips and 25 percent made 37 or more trips in the same period (Table 3). The majority of trips were taken in the summer (12 trips), followed by spring ( 9 trips) and fall ( 7 trips). On average, the fewest number of trips were made in the winter (less than two trips per slip renter). When asked to compare the number of boating trips made last year to the previous three years, 54 percent of the renters felt

\footnotetext{
1 Forty-four percent of the sampled slip renters had permanent residences within 30 miles of their marina. Therefore, a large proportion of trips are local in origin.
} 
that they had made about the same number of boating trips. Thirteen percent said they had taken more trips last year than in the previous three years, and 33 percent said they had taken fewer trips (Figure 12).

Table 3. Number of boating trips to Truman Lake Marina the previous year (09/01/1998 to 08/31/1999).

\begin{tabular}{|c|c|c|c|c|c|c|c|c|}
\hline & \multirow[b]{2}{*}{ Average } & \multirow[b]{2}{*}{ Std. Error } & \multirow[b]{2}{*}{ Minimum } & \multirow[b]{2}{*}{ Maximum } & \multicolumn{3}{|c|}{ Percentiles } & \multirow[b]{2}{*}{$\mathrm{N}$} \\
\hline & & & & & $25 \%$ & $50 \%$ & $75 \%$ & \\
\hline Total number of trips & 29.55 & 2.47 & 0 & 282 & 10 & 20 & 37 & 196 \\
\hline Trips made in fall & 6.96 & 0.77 & 0 & 90 & 2 & 4 & 8 & 191 \\
\hline Trips made in winter & 1.86 & 0.58 & 0 & 90 & 0 & 0 & 0 & 192 \\
\hline Trips made in spring & 8.85 & 0.91 & 0 & 90 & 2 & 5 & 10 & 194 \\
\hline Trips made in summer & 11.72 & 0.90 & 0 & 90 & 3 & 9 & 15 & 194 \\
\hline
\end{tabular}

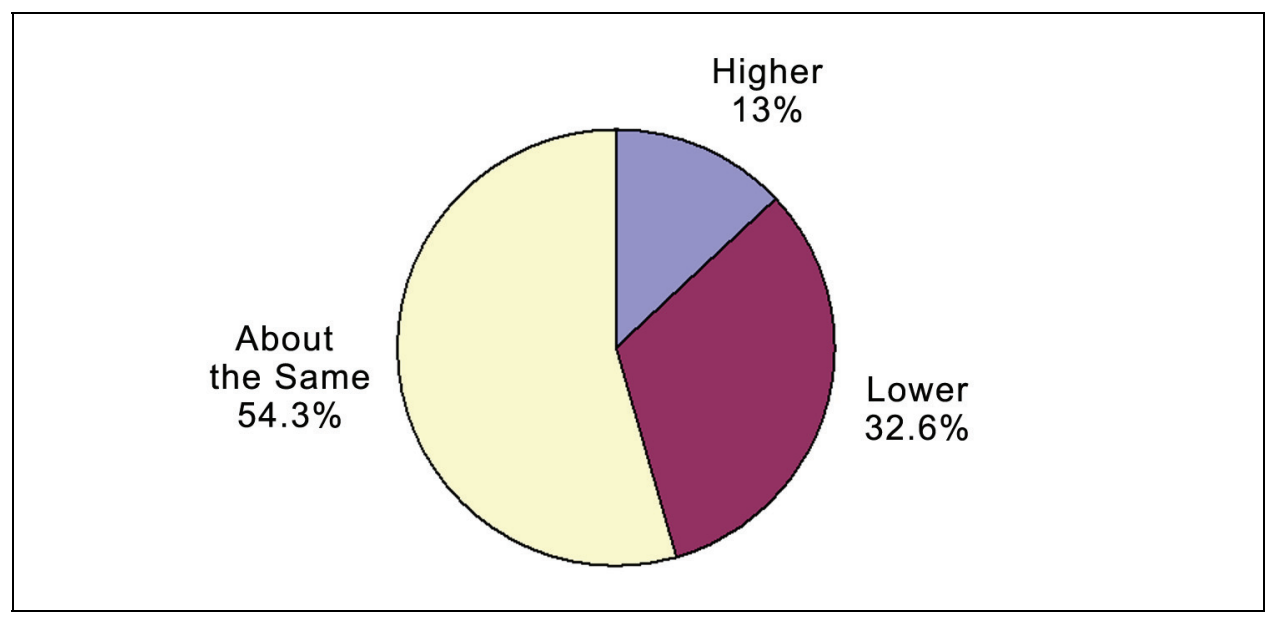

Figure 12. Number of boating trips made by marina slip renters last year compared to previous 3-year average at Truman Lake, 1999 ( $\mathrm{N}=184)$.

\section{Activities while boating}

During their boating trips the previous year, slip renters/users went fishing from their boats an average of 23 times during more than threefourths of their trips (Table 4). Other activities they participated in during their boating trips including swimming (on 32 percent of their boating trips), picnicking (21 percent), water skiing (12 percent), and camping (6 percent each). The participation rates for scuba diving and hunting were both about 1 percent of the total boating trips. Thirty-one percent of the slip renters/users reported participating in other activities that were not listed during the telephone interviews (Figure 13). On average, slip 
renters/users participated in other activities 5 times during 15 percent of their boating trips the previous year (Table 4). The most frequent other activities were tubing and wave running (11 percent of respondents), other nonwater activities (9 percent), sightseeing (3 percent), and jet skiing (3 percent) (Figure 13).

Table 4. Recreation activity participation during previous year's boating trips to Truman Lake Marina (09/01/1998 to 08/31/1999).

\begin{tabular}{|l|l|l|l|l|l|l|}
\hline Activity & Mean & $\begin{array}{l}\text { Percent of } \\
\text { Total Trips }\end{array}$ & $\begin{array}{l}\text { Std. Eror } \\
\text { of Mean }\end{array}$ & Minimum & Maximum & N \\
\hline \hline Boating & 25.02 & $85 \%$ & 2.39 & 0 & 200 & 186 \\
\hline Swimming & 9.50 & $32 \%$ & 1.47 & 0 & 200 & 191 \\
\hline Picnicking & 6.08 & $21 \%$ & 0.88 & 0 & 80 & 191 \\
\hline Fishing from boat & 23.10 & $78 \%$ & 2.31 & 0 & 200 & 189 \\
\hline Water skiing & 3.56 & $12 \%$ & 1.03 & 0 & 112 & 191 \\
\hline Camping & 1.77 & $6 \%$ & 0.37 & 0 & 35 & 190 \\
\hline Hiking & 1.32 & $4 \%$ & 0.71 & 0 & 130 & 190 \\
\hline Fishing from shore & 1.46 & $5 \%$ & 0.36 & 0 & 35 & 190 \\
\hline Scuba diving & 0.17 & $1 \%$ & 0.09 & 0 & 15 & 191 \\
\hline Hunting & 0.29 & $1 \%$ & 0.10 & 0 & 12 & 191 \\
\hline Other activities & 4.51 & $15 \%$ & 1.13 & 0 & 122 & 187 \\
\hline \hline $\begin{array}{l}\text { 1 Times participated in listed activity during previous year's boating trip. } \\
\text { 2 Times participated in the listed activity divided by total number of boating trips made the previous year. }\end{array}$ \\
\hline
\end{tabular}

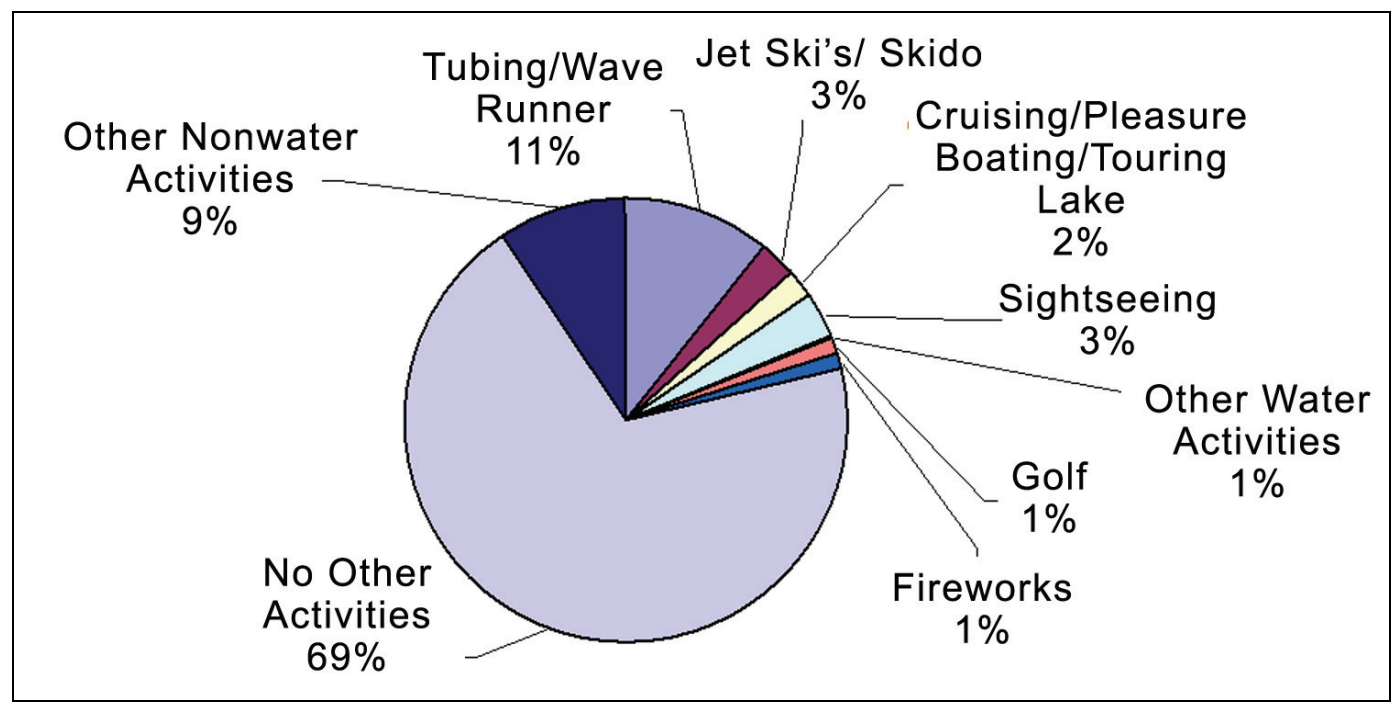

Figure 13. What other activities did you or others participate in during your boating trips last year that I have not already mentioned?" (from Truman Lake Marina, 1999, N=192). 


\section{Type of boat and motor}

Of the boats surveyed at Truman Lake marinas, 49 percent of the boats were 21 to $30 \mathrm{ft}$ long, 47 percent were $20 \mathrm{ft}$ and under with a minimum of $15 \mathrm{ft}$ (Table 5), and 4.5 percent were $31 \mathrm{ft}$ and larger with a maximum of $44 \mathrm{ft}$. Open and pontoon boats were mostly $30 \mathrm{ft}$ and smaller, while cabin cruisers were mostly 21 to $30 \mathrm{ft}$ long.

Table 5. Boat type and length cross-tabulation, Truman Lake Marina slip renter survey, $1999(\mathrm{~N}=202)$.

\begin{tabular}{|c|c|c|c|c|c|c|c|}
\hline \multirow[b]{2}{*}{ Boat Length } & \multicolumn{6}{|c|}{ Boat Type } & \multirow[b]{2}{*}{ Total } \\
\hline & Open & Cabin & Sailboat & Pontoon & Houseboat & Other & \\
\hline 20 and smaller & $20.79 \%$ & $0.99 \%$ & $0.00 \%$ & $24.75 \%$ & $0.00 \%$ & $0.00 \%$ & $46.53 \%$ \\
\hline $21^{\prime}$ to $30^{\prime}$ & $8.91 \%$ & $3.47 \%$ & $0.50 \%$ & $35.15 \%$ & $0.50 \%$ & $0.50 \%$ & $49.01 \%$ \\
\hline 31' and larger & $0.00 \%$ & $0.50 \%$ & $0.00 \%$ & $0.50 \%$ & $3.47 \%$ & $0.00 \%$ & $4.46 \%$ \\
\hline Total & $29.70 \%$ & $4.95 \%$ & $0.50 \%$ & $60.40 \%$ & $3.96 \%$ & $0.50 \%$ & $100.00 \%$ \\
\hline
\end{tabular}

Eighty-six percent of the boats used at marinas did not have inboard motors. The majority of cabin cruisers, and houseboats had inboard motors, while most open boats and pontoons did not (Table 6). In general the small and medium-sized boats (30 ft and smaller) had the higher percentage of outboard motors (Table 7 ).

Table 6. Boat type and motor cross-tabulation, Truman Lake Marina slip renter survey, 1999 (N=201).

\begin{tabular}{|c|c|c|c|c|c|c|c|}
\hline \multirow[b]{2}{*}{ Inboard Motor } & \multicolumn{6}{|c|}{ Boat Type } & \multirow[b]{2}{*}{ Total } \\
\hline & Open & Cabin & Sailboat & Pontoon & Houseboat & Other & \\
\hline With & $5.97 \%$ & $3.48 \%$ & $0.00 \%$ & $\bar{~} 1.49 \%$ & $2.99 \%$ & $0.00 \%$ & $13.93 \%$ \\
\hline Without & $23.88 \%$ & $1.49 \%$ & $0.50 \%$ & $58.71 \%$ & $1.00 \%$ & $0.50 \%$ & $86.07 \%$ \\
\hline Total & $29.85 \%$ & $4.98 \%$ & $0.50 \%$ & $60.20 \%$ & $3.98 \%$ & $0.50 \%$ & $100.00 \%$ \\
\hline
\end{tabular}

Table 7. Boat length and motor cross-tabulation, Truman Lake Marina slip renter survey, $1999(\mathrm{~N}=201)$.

\begin{tabular}{|c|c|c|c|c|}
\hline \multirow[b]{2}{*}{ Inboard Motor } & \multicolumn{3}{|c|}{ Boat Length } & \multirow[b]{2}{*}{ Total } \\
\hline & $20^{\prime}$ and Smaller & $21^{\prime}$ to $30^{\prime}$ & 31' and Larger & \\
\hline With & $4.48 \%$ & $6.47 \%$ & $2.99 \%$ & $13.93 \%$ \\
\hline Without & $41.79 \%$ & $42.79 \%$ & $1.49 \%$ & $86.07 \%$ \\
\hline Total & $46.27 \%$ & $49.25 \%$ & $4.48 \%$ & $100.00 \%$ \\
\hline
\end{tabular}




\section{Slip user segments and spending}

Spending averages were estimated for all Truman Lake's marina slip users (Table 8) and for two different segments based on length of stay (Table 9) and boat length (Table 10). Dividing visitors into segments helps explain differences in spending across distinct user groups. It gives managers the opportunity to apply these distinct spending profiles to project-level use data. The two types of segments that fulfilled these purposes were: day user versus overnight stay segments and segments based on length of the boat.

\section{Average spending for full sample of slip renters}

Marina slip users averaged $\$ 190$ in trip expenses associated with their last boating trip (for a party of 3.6 people). Slip users stayed away from home an average of 1.5 nights and used their boat 1.9 days during their last trip (Table 8). Eighty-two percent ( $\$ 155$ ) of spending occurred within 30 miles of their marina slip. Of the expenditures made within 30 miles of their marina slip, users spent the most on restaurant meals ( $\$ 27$ per party trip), followed by gas and oil expenses for the boat (\$25), gas and oil for the auto (\$23), other expenses for the boat (\$22), and groceries (\$19). A refined average of 30 boating trips were made from each slip in a marina during the previous year.

Slip renters spent an average of $\$ 762$ annually on slip rentals, $\$ 59$ on storage fees, $\$ 201$ on insurance, and $\$ 221$ on boat repair and maintenance (Table 8). The average cost of the boat was $\$ 14,855$ (1999 dollars). The lowest boat cost was $\$ 733$ and the highest was $\$ 144,059$.

When asked to compare the amount spent on their most recent trip to prior similar trips, 74 percent of the renters felt that they had made about the same expenditures. Thirteen percent said they had spent more on the most recent trip than on similar trips in the past 12 months, and 13 percent said they had spent less (Figure 14). 
Table 8. Summary of Truman Lake Marina slip renters'/users' spending and use profiles, 09/1998 to 08/1999 (spending per party trip).

\begin{tabular}{|c|c|c|c|c|c|c|c|c|}
\hline Spending Categories & Mean & $\begin{array}{l}\text { Std. } \\
\text { Error }\end{array}$ & $\begin{array}{l}\text { Pct. } \\
\text { Error }^{1}\end{array}$ & $\mathrm{~N}$ & $\begin{array}{l}\text { Mini- } \\
\text { mum }\end{array}$ & $\begin{array}{l}\text { Maxi- } \\
\text { mum }\end{array}$ & \begin{tabular}{|c} 
Pct. \\
Zeroes
\end{tabular} & $\begin{array}{l}\text { Mean } \\
\text { Exc. Zero }\end{array}$ \\
\hline \multicolumn{9}{|c|}{ Spending Information for Last Trip } \\
\hline Gas/oil auto & $\$ 22.79$ & $\$ 2.92$ & $13 \%$ & 192 & $\$ 0$ & $\$ 350$ & $16 \%$ & $\$ 27.18$ \\
\hline Other expenses auto & $\$ 6.99$ & $\$ 2.35$ & $34 \%$ & 197 & $\$ 0$ & $\$ 300$ & $86 \%$ & $\$ 51.04$ \\
\hline Gas/oil boat & $\$ 24.95$ & $\$ 2.70$ & $11 \%$ & 195 & $\$ 0$ & $\$ 360$ & $14 \%$ & $\$ 29.13$ \\
\hline Other expenses boat & $\$ 22.02$ & $\$ 9.05$ & $41 \%$ & 194 & $\$ 0$ & $\$ 1,300$ & $88 \%$ & $\$ 185.70$ \\
\hline Food/drink restaurants & $\$ 27.49$ & $\$ 3.23$ & $12 \%$ & 197 & $\$ 0$ & $\$ 365$ & $38 \%$ & $\$ 44.39$ \\
\hline Groceries & $\$ 19.49$ & $\$ 2.86$ & $15 \%$ & 195 & $\$ 0$ & $\$ 300$ & $52 \%$ & $\$ 40.43$ \\
\hline Campground fees & $\$ 4.72$ & $\$ 1.81$ & $38 \%$ & 197 & $\$ 0$ & $\$ 225$ & $93 \%$ & $\$ 66.36$ \\
\hline Lodging & $\$ 11.40$ & $\$ 5.23$ & $46 \%$ & 199 & $\$ 0$ & $\$ 865$ & $94 \%$ & $\$ 189.00$ \\
\hline Recreation fees & $\$ 1.43$ & $\$ 0.74$ & $52 \%$ & 199 & $\$ 0$ & $\$ 100$ & $96 \%$ & $\$ 40.71$ \\
\hline Sporting goods & $\$ 3.49$ & $\$ 0.79$ & $23 \%$ & 198 & $\$ 0$ & $\$ 80$ & $81 \%$ & $\$ 18.21$ \\
\hline Other supplies & $\$ 10.33$ & $\$ 1.87$ & $18 \%$ & 198 & $\$ 0$ & $\$ 250$ & $47 \%$ & $\$ 19.66$ \\
\hline Total within 30 miles & $\$ 155.10$ & & & & & & & \\
\hline Expenses for $30+$ miles $^{2}$ & $\$ 35.08$ & $\$ 9.66$ & $28 \%$ & 194 & $\$ 0$ & $\$ 1,500$ & $96 \%$ & \\
\hline Total trip spending 2 & $\$ 190.17$ & & & & & & & \\
\hline $\begin{array}{l}\text { Pct. of local spending } \\
\text { (within } 30 \text { miles) }\end{array}$ & $81.56 \%$ & & & & & & & \\
\hline \multicolumn{9}{|c|}{ Use Information for Last Trip } \\
\hline Nights away from home & 1.47 & 0.16 & $11 \%$ & 201 & 0 & 20 & & \\
\hline Days used boat & 1.94 & 0.12 & $6 \%$ & 201 & 1 & 18 & & \\
\hline $\begin{array}{l}\text { Number of people on } \\
\text { boat }\end{array}$ & 3.56 & 0.16 & $4 \%$ & 200 & 1 & 12 & & \\
\hline \multicolumn{9}{|c|}{ Annual Spending for Last Year (09/01/98 - 08/31/99) } \\
\hline Slip rental & $\$ 761.80$ & $\$ 23.69$ & $3 \%$ & 193 & $\$ 400$ & $\$ 2,400$ & & \\
\hline Storage fees & $\$ 59.42$ & $\$ 10.37$ & $17 \%$ & 194 & $\$ 0$ & $\$ 1,000$ & & \\
\hline Insurance payments & $\$ 201.39$ & $\$ 10.14$ & $5 \%$ & 183 & $\$ 0$ & $\$ 800$ & & \\
\hline Repair/maintenance & $\$ 220.61$ & $\$ 54.65$ & $25 \%$ & 195 & $\$ 0$ & $\$ 10,000$ & & \\
\hline \multicolumn{9}{|c|}{ Use Information for Last Year (09/01/98 - 08/31/99) } \\
\hline $\begin{array}{l}\text { Number of trips using } \\
\text { boat }\end{array}$ & 29.68 & 2.48 & $8 \%$ & 195 & 0 & 282 & & \\
\hline $\begin{array}{l}\text { Cost of the boat } \\
\text { (in } 1999 \text { dollars) }\end{array}$ & $\$ 14,854.81$ & $\$ 1,014.52$ & $7 \%$ & 189 & $\$ 733$ & $\$ 144,059$ & & \\
\hline
\end{tabular}




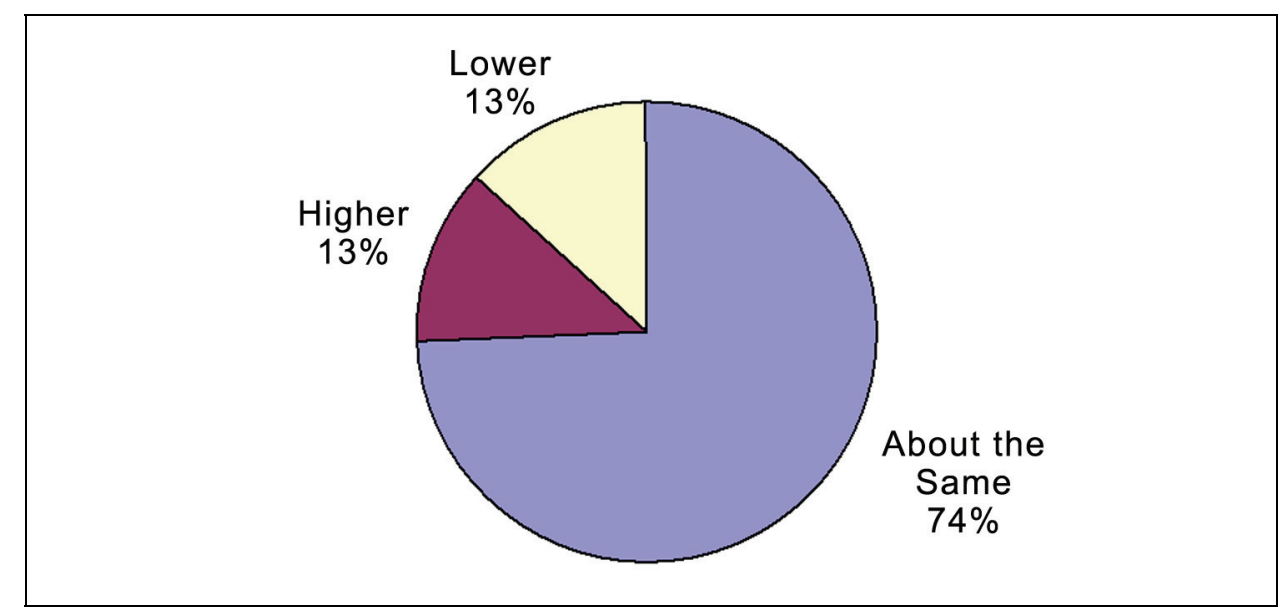

Figure 14. Expenditures by marina slip renters/users on most recent trip compared to similar trips in the last 12 months at Truman Lake, $1999(\mathrm{~N}=197)$.

Many of the respondents reported no spending on their last trip in many of the spending categories listed. Categories in which a large percentage (more than 80 percent) of users did not spend money on their last trip were: other expenses on auto (86 percent), other expenses on boat ( 88 percent), campground fees (93 percent), lodging (94 percent), recreation fees (96 percent), and sporting goods (81 percent). Although the estimates of average trip expenditures in this report are based on the full sample, it is worthwhile to recognize the difference between the average spending of all marina slip users and average spending of just the spenders. The average spending of those who spent something on an item is generally much higher than the average computed from all visitors. For instance, while the average across all slip users was $\$ 11.40$ on lodging per party trip, the 12 marina slip parties who did spend money on lodging spent an average of $\$ 189$ per party trip (Table 8 ). For estimating total spending of all Truman marina slip users, it is appropriate to apply the means that include zeros. The means without zeros should not be used to expand the data to population totals, as they only represent spending for specific segments (i.e., slip users who stayed in hotels spent an average of $\$ 189$ on lodging per trip).

\section{Average spending by segment: Day use vs. overnight}

Truman slip renters were grouped into two segments based on whether or not they stayed overnight away from their permanent home during their last trip. The slip renters/users who did not stay away from home (i.e., day users) spent an average of $\$ 74$ for that trip, 93 percent (\$69) of which was spent within 30 miles of the marina slip (Table 9). The average party size 
Table 9. Spending and use by length of stay segments, Truman Lake Marina slip renter survey, 09/1998 to 08/1999 (spending per party trip).

\begin{tabular}{|c|c|c|c|c|c|c|c|c|}
\hline \multirow[b]{2}{*}{ Spending Categories } & \multicolumn{4}{|c|}{ Day Users } & \multicolumn{4}{|c|}{ Overnight Users } \\
\hline & Mean & $\begin{array}{l}\text { Std. } \\
\text { Error }\end{array}$ & $\begin{array}{l}\text { Pct. } \\
\text { Error }^{1}\end{array}$ & $\mathrm{~N}$ & Mean & $\begin{array}{l}\text { Std. } \\
\text { Error }\end{array}$ & $\begin{array}{l}\text { Pct. } \\
\text { Error }^{1}\end{array}$ & $\mathrm{~N}$ \\
\hline \multicolumn{9}{|c|}{ Per Party Trip Spending } \\
\hline Gas/oil auto & $\$ 9.55$ & $\$ 0.99$ & $10 \%$ & 102 & $\$ 37.79$ & $\$ 5.74$ & $15 \%$ & 90 \\
\hline Other expenses auto & $\$ 2.50$ & $\$ 1.50$ & $60 \%$ & 106 & $\$ 12.23$ & $\$ 4.75$ & $39 \%$ & 91 \\
\hline Gas/oil boat & $\$ 14.94$ & $\$ 1.67$ & $11 \%$ & 104 & $\$ 36.38$ & $\$ 5.23$ & $14 \%$ & 91 \\
\hline Other expenses boat & $\$ 12.48$ & $\$ 7.14$ & $57 \%$ & 106 & $\$ 33.50$ & $\$ 17.99$ & $54 \%$ & 88 \\
\hline Restaurants & $\$ 10.18$ & $\$ 1.82$ & $18 \%$ & 105 & $\$ 47.25$ & $\$ 5.98$ & $13 \%$ & 92 \\
\hline Groceries & $\$ 6.18$ & $\$ 1.57$ & $25 \%$ & 104 & $\$ 34.69$ & $\$ 5.46$ & $16 \%$ & 91 \\
\hline Campground fees & $\$ 0.00$ & - & - & 106 & $\$ 10.21$ & $\$ 3.85$ & $38 \%$ & 91 \\
\hline Lodging & $\$ 0.00$ & - & - & 107 & $\$ 24.65$ & $\$ 11.18$ & $45 \%$ & 92 \\
\hline Recreation fees & $\$ 1.59$ & $\$ 1.01$ & $64 \%$ & 107 & $\$ 1.25$ & $\$ 1.09$ & $87 \%$ & 92 \\
\hline Sporting goods & $\$ 2.26$ & $\$ 0.81$ & $36 \%$ & 106 & $\$ 4.91$ & $\$ 1.42$ & $29 \%$ & 92 \\
\hline Other supplies & $\$ 9.16$ & $\$ 3.09$ & $34 \%$ & 106 & $\$ 11.67$ & $\$ 1.87$ & $16 \%$ & 92 \\
\hline Total within 30 miles & $\$ 68.85$ & & & & $\$ 254.54$ & & & \\
\hline Expenses $30+$ miles $^{2}$ & $\$ 5.50$ & $\$ 1.32$ & $24 \%$ & 103 & $\$ 68.55$ & $\$ 20.02$ & $29 \%$ & 91 \\
\hline Total trip spending & $\$ 74.36$ & & & & $\$ 323.09$ & & & \\
\hline $\begin{array}{l}\text { Pct. of local spending (within } \\
30 \text { miles) }\end{array}$ & $93 \%$ & & & & $79 \%$ & & & \\
\hline \multicolumn{9}{|c|}{ Annual Spending } \\
\hline Slip rental & $\$ 688.61$ & $\$ 22.15$ & $3 \%$ & 104 & $\$ 847.34$ & $\$ 42.79$ & $5 \%$ & 89 \\
\hline Storage fees & $\$ 59.22$ & $\$ 14.36$ & $24 \%$ & 105 & $\$ 59.66$ & $\$ 15.05$ & $25 \%$ & 89 \\
\hline Insurance payments & $\$ 175.06$ & $\$ 12.00$ & $7 \%$ & 99 & $\$ 232.43$ & $\$ 16.41$ & $7 \%$ & 84 \\
\hline Repair/maintenance & $\$ 121.02$ & $\$ 24.34$ & $20 \%$ & 102 & $\$ 329.84$ & $\$ 110.65$ & $34 \%$ & 93 \\
\hline $\begin{array}{l}\text { Cost of the boat (in } 1999 \\
\text { dollars) }\end{array}$ & $\$ 11,363.06$ & $\$ 667.09$ & $6 \%$ & 102 & $\$ 18,948.58$ & $\$ 1978.41$ & $10 \%$ & 87 \\
\hline \multicolumn{9}{|c|}{ Visitor Characteristics } \\
\hline $\begin{array}{l}\text { Total trips using boat (last } \\
\text { year) }\end{array}$ & 34.12 & 3.93 & $12 \%$ & 103 & 24.72 & 2.81 & $11 \%$ & 92 \\
\hline $\begin{array}{l}\text { Nights away from home (last } \\
\text { trip) }\end{array}$ & 0.00 & - & - & 108 & 3.17 & 0.26 & $8 \%$ & 93 \\
\hline Days used boat (last trip) & 1.00 & - & - & 108 & 3.02 & 0.22 & $7 \%$ & 93 \\
\hline People on boat (last trip) & 3.43 & 0.22 & $6 \%$ & 108 & 3.71 & 0.22 & $6 \%$ & 92 \\
\hline
\end{tabular}

was 3.4 people per trip. The slip renters/users who stayed overnight spent an average of 3.2 nights away from home and used the boat for 3 days with a party size of 3.7 people per trip. They spent an average $\$ 323$ for the 
entire trip, 79 percent (\$255) of which was spent within 30 miles of the marina slip. Day users made an average of 34 boating trips in the previous year, whereas overnighters made 25 trips.

Slip renters in the overnight segment owned more expensive boats than day users ( $\$ 18,949$ vs. $\$ 11,363$, respectively). Consequently, they paid more annually in slip rentals fees, insurance payments, and repairs and maintenance than day users.

Day use and overnight stay segments were almost evenly split in the sample. Day users comprised 53 percent of the sample of marina slip users, while 47 percent spent a least one night in the area on their last trip. In terms of total spending in the local region, day users of marina slips contributed 30 percent, and overnight stay slip users, 70 percent.

\section{Average spending by boat length segments}

Based on the length of the boat, the slip renters were grouped into three segments: boats that were $20 \mathrm{ft}$ and shorter, boats between 21 and $30 \mathrm{ft}$, and boats $31 \mathrm{ft}$ and longer. In general, as boat size increased so did the amount of expenditures, particularly when going from the middle to the longest category. The 20-ft and smaller segment spent an average of $\$ 174$ per party on the last trip during which about 79 percent ( $\$ 137$ ) was spent within 30 miles of the marina slip (Table 10). They stayed an average of 1.7 nights away from home and used their boat for 2 days with a party size of 3.2 people per trip. Slip renters/users in this segment made an average of 32 boating trips the previous year.

The 20- to 31- $\mathrm{ft}$ boat segment spent an average of $\$ 194$ per party on the last trip (\$159 within 30 miles of the marina slip). They stayed an average of 1.2 nights away from home, used their boat for 1.9 days, with a party size of 4 people per trip. They made an average of 28 boating trips the previous year. Renters/users in the largest boat size segment averaged more than \$299 per party on goods and services during their last trip, (\$284 of the money was spent locally). They stayed away from home an average of 1.8 nights and used the boat for 2.2 days per trip. The average party size for this group was 3.4 people per trip. Renters/users in this segment made an average of 24 boating trips the previous year. 
Table 10. Spending and use by boat length segments, Truman Lake Marina slip renter survey, 09/1998 to 08/1999 (spending per party trip).

\begin{tabular}{|c|c|c|c|c|c|c|c|c|c|c|c|c|}
\hline \multirow[b]{2}{*}{ Spending Categories } & \multicolumn{4}{|c|}{ 20' and Smaller } & \multicolumn{4}{|c|}{$21^{\prime}$ to $30^{\prime}$} & \multicolumn{4}{|c|}{ 31' and Larger } \\
\hline & Mean & $\begin{array}{l}\text { Std. } \\
\text { Error }\end{array}$ & $\begin{array}{l}\text { Pct. } \\
\text { Error }^{1}\end{array}$ & $\mathrm{~N}$ & Mean & $\begin{array}{l}\text { Std. } \\
\text { Error }\end{array}$ & $\begin{array}{l}\text { Pct. } \\
\text { Error }^{1}\end{array}$ & $\mathrm{~N}$ & Mean & $\begin{array}{l}\text { Std. } \\
\text { Error }\end{array}$ & $\begin{array}{l}\text { Pct. } \\
\text { Error }^{1}\end{array}$ & $\mathrm{~N}$ \\
\hline \multicolumn{13}{|c|}{ Per Party Trip Spending } \\
\hline Gas/oil auto & $\$ 23.27$ & $\$ 4.15$ & $18 \%$ & 90 & $\$ 22.96$ & $\$ 4.47$ & $19 \%$ & 93 & $\$ 16.22$ & $\$ 5.27$ & $33 \%$ & 9 \\
\hline Other expenses auto & $\$ 12.43$ & $\$ 4.83$ & $39 \%$ & 92 & $\$ 1.30$ & $\$ 0.52$ & $40 \%$ & 96 & $\$ 12.11$ & $\$ 12.11$ & $100 \%$ & 9 \\
\hline Gas/oil boat & $\$ 20.16$ & $\$ 2.48$ & $12 \%$ & 89 & $\$ 28.59$ & $\$ 4.64$ & $16 \%$ & 97 & $\$ 33.11$ & $\$ 18.18$ & $55 \%$ & 9 \\
\hline Other expenses boat & $\$ 12.42$ & $\$ 5.82$ & $47 \%$ & 88 & $\$ 18.85$ & $\$ 11.17$ & $59 \%$ & 97 & $\$ 150.00$ & $\$ 143.86$ & $96 \%$ & 9 \\
\hline Restaurants & $\$ 29.25$ & $\$ 4.56$ & $16 \%$ & 91 & $\$ 26.02$ & $\$ 4.96$ & $19 \%$ & 97 & $\$ 25.56$ & $\$ 6.26$ & $24 \%$ & 9 \\
\hline Groceries & $\$ 17.45$ & $\$ 3.98$ & $23 \%$ & 89 & $\$ 21.15$ & $\$ 4.37$ & $21 \%$ & 97 & $\$ 21.67$ & $\$ 10.47$ & $48 \%$ & 9 \\
\hline Campground fees & $\$ 5.65$ & $\$ 2.68$ & $47 \%$ & 91 & $\$ 4.28$ & $\$ 2.70$ & $63 \%$ & 97 & $\$ 0.00$ & $\$ 0.00$ & - & 9 \\
\hline Lodging & $\$ 1.09$ & $\$ 0.78$ & $72 \%$ & 92 & $\$ 21.59$ & $\$ 10.51$ & $49 \%$ & 98 & $\$ 5.78$ & $\$ 5.78$ & $100 \%$ & 9 \\
\hline Recreation fees & $\$ 2.83$ & $\$ 1.59$ & $56 \%$ & 92 & $\$ 0.26$ & $\$ 0.15$ & $0 \%$ & 98 & $\$ 0.00$ & $\$ 0.00$ & - & 9 \\
\hline Sporting goods & $\$ 2.65$ & $\$ 0.96$ & $36 \%$ & 92 & $\$ 3.97$ & $\$ 1.25$ & $31 \%$ & 97 & $\$ 7.00$ & $\$ 5.39$ & $77 \%$ & 9 \\
\hline Other supplies & $\$ 10.27$ & $\$ 2.65$ & $26 \%$ & 92 & $\$ 10.13$ & $\$ 2.84$ & $28 \%$ & 97 & $\$ 13.00$ & $\$ 5.05$ & $39 \%$ & $\underline{9}$ \\
\hline Total within 30 miles & $\$ 137.47$ & & & & $\$ 159.10$ & & & & $\$ 284.44$ & & & \\
\hline Expenses $30+$ miles $^{2}$ & $\$ 36.76$ & $\$ 12.28$ & $33 \%$ & 89 & $\$ 35.40$ & $\$ 15.90$ & $45 \%$ & 96 & $\$ 15.00$ & $\$ 6.56$ & $44 \%$ & 9 \\
\hline Total trip spending & $\$ 174.24$ & & & & $\$ 194.49$ & & & & $\$ 299.44$ & & & \\
\hline Pct. of local spending (within 30 miles) & $79 \%$ & & & & $82 \%$ & & & & $95 \%$ & & & \\
\hline \multicolumn{13}{|c|}{ Annual Spending } \\
\hline Slip rental & $\$ 676.33$ & $\$ 15.25$ & $2 \%$ & 89 & $\$ 741.11$ & $\$ 25.02$ & $3 \%$ & 95 & $\$ 1,825.56$ & $\$ 186.97$ & $10 \%$ & 9 \\
\hline Storage fees & $\$ 32.92$ & $\$ 10.66$ & $32 \%$ & 89 & $\$ 89.56$ & $\$ 17.99$ & $20 \%$ & 96 & $\$ 0.00$ & $\$ 0.00$ & - & 9 \\
\hline Insurance payments & $\$ 170.13$ & $\$ 11.65$ & $7 \%$ & 88 & $\$ 210.78$ & $\$ 14.47$ & $7 \%$ & 87 & $\$ 443.25$ & $\$ 67.76$ & $15 \%$ & 8 \\
\hline Repair/maintenance & $\$ 152.45$ & $\$ 33.46$ & $22 \%$ & 89 & $\$ 180.94$ & $\$ 28.71$ & $16 \%$ & 97 & $\$ 1,322.22$ & $\$ 1086.79$ & $82 \%$ & 9 \\
\hline Cost of the boat (in 1999 dollars) & $\$ 13,082.01$ & $\$ 1,629.24$ & $12 \%$ & 88 & $\$ 14,928.29$ & $\$ 1,121.18$ & $8 \%$ & 93 & $\$ 33,501.48$ & $\$ 6,594.36$ & $20 \%$ & 8 \\
\hline \multicolumn{13}{|c|}{ Visitor Characteristics } \\
\hline Total trips using boat (last year) & 31.81 & 4.35 & $14 \%$ & 89 & 28.25 & 2.95 & $10 \%$ & 97 & 24.11 & 5.89 & $24 \%$ & 9 \\
\hline Nights away from home (last trip) & 1.69 & 0.29 & $17 \%$ & 94 & 1.22 & 0.17 & $14 \%$ & 98 & 1.78 & 0.40 & $23 \%$ & 9 \\
\hline Days used boat (last trip) & 1.99 & 0.22 & $11 \%$ & 94 & 1.86 & 0.14 & $8 \%$ & 98 & 2.22 & 0.32 & $15 \%$ & 9 \\
\hline People on boat (last trip) & 3.17 & 0.20 & $6 \%$ & 94 & 3.94 & 0.25 & $6 \%$ & 98 & 3.38 & 0.50 & $15 \%$ & 8 \\
\hline
\end{tabular}


In general, the larger the boat, the more slip renters spent on annual expenses. Slip rentals ranged from $\$ 676$ for boats $20 \mathrm{ft}$ and shorter to $\$ 1,826$ for boats $31 \mathrm{ft}$ and longer. The cost of the boat ranged from $\$ 13,082$ for the $20-\mathrm{ft}$ and smaller segment to $\$ 33,501 \mathrm{for}$ the $31 \mathrm{ft}$ and larger segment, while the insurance payments ranged from $\$ 170$ to $\$ 443$ per year across the three segments. Boat repair and maintenance costs similarly grew from $\$ 152$ to $\$ 1,322$ per year as boat size increased (Table 10).

Half the sample had medium-sized boats ( 21 to $30 \mathrm{ft}$ ), while the other half were small (under $21 \mathrm{ft}$ ) and a small percentage were large (above $30 \mathrm{ft}$ ). Slip users with large boats contributed 7 percent of total spending locally, slip users with medium-sized boats, 48 percent, and those with small boats, 45 percent.

\section{Total spending}

The figures in Table 11 were derived from secondary data sources, the Natural Resource Management System (NRMS) (USACE 2006c), and from survey data for Truman Lake (e.g., average number of trips per boat last year). The 78-percent occupancy rate for marina slips came from the 1999 NRMS database. Based on the assumption that there was one boat for each occupied slip, the total number of 835 boats used by slip users at Truman Lake was computed by multiplying the occupancy rate by the total number of wet slips (1,070 from NRMS). Truman slip users took 24,659 boating party trips in 1999 (4.6 percent of total recreation use ${ }^{1}$ ) and purchased 34 new boats (Table 11).

Local and total trip-related spending (Tables 12 and 13) is calculated by multiplying the number of party-trips in Table $11(24,659)$ by the trip spending averages in Table 8 . Total spending on boats and fixed, annual goods and services (Table 14) is estimated by multiplying the number of boats in Table 11 (835) by the annual expenditures on boats, slip rental fees, boat repairs and maintenance, and storage in Table 8. Total spending on insurance is estimated by multiplying the number of boats (835) by the proportion of local boat owners who purchased boat insurance and their average insurance payment. Total spending on purchasing new boats is estimated by multiplying the number of new boats purchased last year

\footnotetext{
11.6 million recreation visits in 1999 from Table 1 divided by an average party size of 3.0 from Propst et al. (1998) equals 533,000 total party trips; 24,659 is 4.6 percent of 533,000 party trips.
} 
(34) by the proportion of local slip renters who bought new boats and the average local new boat cost for three years: 1997-1999.

Table 11. Total annual use figures for marina slip renter survey at Truman Lake (1999).

\begin{tabular}{|l|l|l||}
\hline Category & Total Use & Computation Procedures \\
\hline \hline Occupancy rate & $78.00 \%$ & 1From NRMS (1999) \\
\hline Number of slips & 1,070 & 1From NRMS (1999) \\
\hline Number of boats & 835 & $\begin{array}{l}\text { Number of slips times occu- } \\
\text { pancy rate }\end{array}$ \\
\hline Number of party trips & 24,659 & $\begin{array}{l}\text { Total party trips (from Table 3) } \\
\text { times total number of boats } \\
\text { (Reference Foreword) }\end{array}$ \\
\hline Percent of new boats purchased last year & $4.13 \%$ & $\begin{array}{l}\text { Computed from survey results, } \\
\text { using the 3-year average } \\
\text { (1997 to 1999) }\end{array}$ \\
\hline Number of new boats purchased last year & 34 & $\begin{array}{l}\text { Total boats times percent of } \\
\text { new boats purchased last year }\end{array}$ \\
\hline \hline 1 Those numbers were quoted from project level marina slip study parameter (1999).
\end{tabular}

A recreation visit, as reported in the NRMS database, is one person entering a Corps project. Spending depends on how long a person stays in the local region rather than how many times they enter the project or how much time they spend in recreation activities while there. Recreation visits are therefore converted to party trips ${ }^{1}$ in the region before applying spending averages. This procedure avoids double-counting the spending of marina slip users who may enter the project multiple times on the same day and also takes into account additional days a slip user may spend in the area outside the project.

The estimated trip spending for all Truman marina slip users in 1999 was $\$ 3.8$ million spent within the local region (Table 12). If trip spending outside 30 miles is included, the total rises to $\$ 4.7$ million (Table 13). Only trip spending within 30 miles of the marina slip ( $\$ 3.8$ million) should be included when conducting economic impact analysis at the project level (multi-county region).

\footnotetext{
1 See Table 11 for the conversion steps. A party is a travel group staying in the area (within 30 miles of the marina). The travel group is usually all individuals in the same vehicle or on the same boat or staying in the same room or campsite. During the interviews, slip renters were asked to report expenditures for their entire party for the last trip. Thus, the units for expenditures are party trips. Converting visits to party trips assures that the units are the same in the multiplication steps that lead to estimates of total expenditures (visits in party trips times expenditures in party trips).
} 
Table 12. Total trip spending in local area ${ }^{1}$ by Truman Lake Marina slip renters/users (1999).

\begin{tabular}{|l|l|}
\hline Spending Category & Spending (\$MM) \\
\hline \hline Gas/oil auto & $\$ 0.56$ \\
\hline Other expenses auto & $\$ 0.17$ \\
\hline Gas/oil boat & $\$ 0.62$ \\
\hline Other expenses boat & $\$ 0.54$ \\
\hline Food/drink restaurants & $\$ 0.68$ \\
\hline Groceries & $\$ 0.48$ \\
\hline Campground fees & $\$ 0.12$ \\
\hline Lodging & $\$ 0.28$ \\
\hline Recreation fees & $\$ 0.04$ \\
\hline Sporting goods & $\$ 0.09$ \\
\hline Other supplies & $\$ 0.25$ \\
\hline Total trip spending & $\$ 3.82$ \\
\hline \hline 1 Local trip spending equals spending within 30 miles of the slip. & \\
\hline
\end{tabular}

Table 13. Total trip spending1 by Truman Lake Marina slip renters/users (1999).

\begin{tabular}{|l|l||}
\hline Spending Category & Spending (\$MM) ${ }^{2}$ \\
\hline \hline Gas/oil auto & $\$ 0.74$ \\
\hline Other expenses auto & $\$ 0.23$ \\
\hline Gas/oil boat & $\$ 0.62$ \\
\hline Other expenses boat & $\$ 0.54$ \\
\hline Food/drink restaurants & $\$ 0.90$ \\
\hline Groceries & $\$ 0.64$ \\
\hline Campground fees & $\$ 0.15$ \\
\hline Lodging & $\$ 0.37$ \\
\hline Recreation fees & $\$ 0.05$ \\
\hline Sporting goods & $\$ 0.11$ \\
\hline Other supplies & $\$ 0.34$ \\
\hline Total trip spending & $\$ 4.69$ \\
\hline \hline $\begin{array}{l}1 \text { Total trip spending equals spending within and outside } 30 \text { miles of the slip. } \\
2 \text { Slip renters were asked to report trip spending outside 30 miles of the marina slip as one total amount, } \\
\text { not broken down by item as this table shows. This aggregate spending figure was then proportionally dis- } \\
\text { tributed into all but two categories based on the spending proportions within } 30 \text { miles. Proportional alloca- } \\
\text { tions were not made to the "gas/oil boat" and "other expenses boat" categories. It was assumed that, for } \\
\text { these two categories, there were no boating expenditures outside 30 miles of the marina slip. }\end{array}$ \\
\hline
\end{tabular}


Fixed, annual goods and services related to boating activities in this study were new boats, slip rental fees, storage fees, insurance, and repairs and maintenance. Truman's marina slip renters spent \$1.2 million (1999 dollars) on boating-related annual goods and services (Table 14). Fifty-five percent of the money was spent on slip rental fees $(\$ 640,000)$, followed by purchases of new boats $(\$ 210,000)$, repairs/maintenance $(\$ 180,000)$, insurance $(\$ 70,000)$, and storage fees $(\$ 50,000)$.

Table 14. Total spending on fixed, annual goods and services by marina slip renters at Truman Lake (1999).

\begin{tabular}{|l|l|}
\hline Spending Category & Spending (\$MM) \\
\hline \hline Slip rentals & $\$ 0.64$ \\
\hline Storage fees & $\$ 0.05$ \\
\hline $\begin{array}{l}\text { Insurance payments (include only payments from slip renters who } \\
\text { lived within 30 miles of the marina) }\end{array}$ & $\$ 0.07$ \\
\hline Repair/maintenance & $\$ 0.18$ \\
\hline Purchases of new boats (within 30 miles) & $\$ 0.21$ \\
\hline Total durable goods spending & $\$ 1.15$ \\
\hline
\end{tabular}

\section{Economic impacts of slip user spending}

\section{9 impacts}

The \$3.8 million in trip-related spending from Table 12 had a direct economic impact on the region of $\$ 2.4$ million in direct sales, $\$ 790,000$ in personal income (wages and salaries), and supported 58 jobs in the region (Table 15). The eating and drinking (restaurants and bars) sector received the largest amount of direct sales $(\$ 680,000)$ followed by the retail trade sector $(\$ 490,000)$.

Direct effects are less than total spending, as only the retail and wholesale margins on visitor purchases of goods accrue to the local economy. The local region surrounding Truman Lake captures 63 percent of slip user spending. Thirty-seven percent leaks out of the local economy to cover the costs of imported goods bought by visitors. ${ }^{1}$

1 For example, if a visitor buys $\$ 50$ worth of clothing that is not manufactured in the local region, only the local margins (retail and locally operated wholesale and transportation), say $\$ 30$, will be captured by the local economy as direct sales. The remaining $\$ 20$ will leak immediately outside the local economy to cover the producer price (or price of good at the factory), and non-local margins (wholesale and transportation). 
Table 15. Regional economic impacts of Truman Lake Marina slip renters'/users' trip spending (1999, for trip spending within 30 miles only).

\begin{tabular}{|c|c|c|c|c|}
\hline \multicolumn{5}{|c|}{$\begin{array}{l}\text { Summary Results Table } \\
\text { Impacts on Local Economy }\end{array}$} \\
\hline \multicolumn{2}{|l|}{ Economic Measure } & Direct & Multiplier & Total \\
\hline \multicolumn{2}{|l|}{ Output/sales (\$MM) } & $\$ 2.40$ & 1.45 & $\$ 3.48$ \\
\hline \multicolumn{2}{|l|}{ Total income (\$MM) } & $\$ 0.79$ & 0.47 & $\$ 1.13$ \\
\hline \multicolumn{2}{|l|}{ Total value added (\$MM) } & $\$ 1.20$ & 0.74 & $\$ 1.79$ \\
\hline \multicolumn{2}{|l|}{ Jobs } & 57.85 & 30.89 & 74.17 \\
\hline \multicolumn{3}{|c|}{ Total visitor spending (\$MM) } & \multicolumn{2}{|l|}{3.82} \\
\hline \multicolumn{3}{|l|}{ Capture rate } & \multicolumn{2}{|l|}{$63 \%$} \\
\hline \multicolumn{3}{|c|}{ Effective spending multiplier } & \multicolumn{2}{|l|}{0.91} \\
\hline \multicolumn{5}{|c|}{ Direct Effects } \\
\hline Sector & Sales (\$MM) & Income (\$MM) & $\begin{array}{l}\text { Value Added } \\
\text { (\$MM) }\end{array}$ & Jobs \\
\hline Lodging & $\$ 0.40$ & $\$ 0.14$ & $\$ 0.22$ & 11.67 \\
\hline Eat and drink & $\$ 0.68$ & $\$ 0.22$ & $\$ 0.31$ & 24.07 \\
\hline Amusement and recreation & $\$ 0.02$ & $\$ 0.01$ & $\$ 0.01$ & 0.83 \\
\hline Retail & $\$ 0.49$ & $\$ 0.23$ & $\$ 0.38$ & 12.40 \\
\hline Wholesale & $\$ 0.11$ & $\$ 0.05$ & $\$ 0.08$ & 1.65 \\
\hline Other services & $\$ 0.25$ & $\$ 0.06$ & $\$ 0.09$ & 2.89 \\
\hline Groceries & $\$ 0.04$ & $\$ 0.01$ & $\$ 0.01$ & 0.21 \\
\hline Sporting goods & $\$ 0.01$ & $\$ 0.00$ & $\$ 0.00$ & 0.10 \\
\hline Other manufacturing & $\$ 0.38$ & $\$ 0.08$ & $\$ 0.09$ & 3.93 \\
\hline Government & $\$ 0.02$ & $\$ 0.00$ & $\$ 0.01$ & 0.10 \\
\hline Total & $\$ 2.40$ & $\$ 0.79$ & $\$ 1.20$ & 57.85 \\
\hline \multicolumn{5}{|c|}{ Total Effects } \\
\hline Sector & Sales (\$MM) & Income (\$MM) & $\begin{array}{l}\text { Value Added } \\
\text { (\$MM) }\end{array}$ & Jobs \\
\hline Lodging & $\$ 0.41$ & $\$ 0.14$ & $\$ 0.22$ & 11.98 \\
\hline Eat and drink & $\$ 0.72$ & $\$ 0.23$ & $\$ 0.33$ & 25.62 \\
\hline Amusement and recreation & $\$ 0.03$ & $\$ 0.01$ & $\$ 0.01$ & 1.14 \\
\hline Retail & $\$ 0.58$ & $\$ 0.27$ & $\$ 0.45$ & 14.88 \\
\hline Wholesale & $\$ 0.17$ & $\$ 0.07$ & $\$ 0.11$ & 2.38 \\
\hline Other services & $\$ 0.89$ & $\$ 0.24$ & $\$ 0.46$ & 11.16 \\
\hline Groceries & $\$ 0.09$ & $\$ 0.01$ & $\$ 0.02$ & 0.41 \\
\hline Sporting goods & $\$ 0.01$ & $\$ 0.00$ & $\$ 0.00$ & 0.10 \\
\hline Other manufacturing & $\$ 0.54$ & $\$ 0.13$ & $\$ 0.16$ & 5.99 \\
\hline Government & $\$ 0.05$ & $\$ 0.02$ & $\$ 0.02$ & 0.52 \\
\hline Total & $\$ 3.48$ & $\$ 1.13$ & $\$ 1.79$ & 74.17 \\
\hline
\end{tabular}


The sales multiplier ${ }^{1}$ for the region is 1.45 , meaning that an additional $\$ 0.45$ in sales is generated through secondary effects for every dollar of direct sales. Secondary effects generate an additional 16 jobs, for a total of 74 direct and secondary jobs (Table 15). Likewise, secondary effects generate an additional $\$ 340,000$ in personal income and $\$ 590,000$ in value added (personal income + proprietor's income + indirect business tax). Roughly 15 direct jobs are supported by each million dollars in total slip user spending. Including multiplier effects, each million dollars in total slip user spending supports about 19 jobs.

The $\$ 1.2$ million in spending on new boats, slip rental fees, storage fees, insurance, and repairs/maintenance from Table 14 had a direct economic impact on the region of $\$ 920,000$ in direct sales, $\$ 120,000$ in personal income (wages and salaries), and supported 7 direct jobs in the region (Table 16). The 'other services' sector received the largest amount of direct sales $(\$ 700,000)$, followed by other manufacturing $(\$ 150,000)$.

Direct effects only accrue to the industries where slip renter spending is directly received. For example, since no money is spent in the Lodging sector from slip renter annual or durable goods spending, that cell is blank in the top sector of Table 16 (direct effects). However, other companies receiving direct payments, e.g. insurance companies may hire employees who live in the region and spend money in the local Lodging sector. Since this is a multiplier (secondary) effect upon the Lodging sector, some amount of sales may appear in the Lodging cell in the total effect sector of Table 16.

The local region surrounding Truman Lake captures 80 percent of slip renter spending on new boats and annual services. Twenty percent leaks out of the local economy to cover the costs of imported boats and services bought by visitors.

\footnotetext{
1 Multipliers for the 4-county region are from a 2000 input-output model estimated with the IMPLAN system.
} 
Table 16. Regional economic impacts of Truman Lake Marina slip renters' durable goods and annual spending (1999).

\begin{tabular}{|c|c|c|c|c|}
\hline \multicolumn{5}{|c|}{$\begin{array}{l}\text { Summary Results Table } \\
\text { Impacts on Local Economy }\end{array}$} \\
\hline \multicolumn{2}{|l|}{ Economic Measure } & Direct & Multiplier & Total \\
\hline \multicolumn{2}{|l|}{ Output/sales (\$MM) } & $\$ 0.92$ & 1.39 & \$1.28 \\
\hline \multicolumn{2}{|l|}{ Total income (\$MM) } & $\$ 0.12$ & 0.25 & $\$ 0.23$ \\
\hline \multicolumn{2}{|l|}{ Total value added (\$MM) } & $\$ 0.17$ & 0.38 & $\$ 0.35$ \\
\hline \multicolumn{2}{|l|}{ Jobs } & 7.13 & 13.25 & $\$ 12.19$ \\
\hline & \multicolumn{2}{|c|}{ Total visitor spending (\$MM) } & \multicolumn{2}{|l|}{1.15} \\
\hline & \multicolumn{2}{|c|}{ Capture rate } & \multicolumn{2}{|l|}{$80 \%$} \\
\hline & \multicolumn{2}{|c|}{ Effective spending multiplier } & \multicolumn{2}{|l|}{1.11} \\
\hline \multicolumn{5}{|c|}{ Direct Effects } \\
\hline Sector & Sales (\$MM) & Income (\$MM) & $\begin{array}{l}\text { Value Added } \\
\text { (\$MM) }\end{array}$ & Jobs \\
\hline Lodging & \$- & $\overline{~ \$-}$ & $\$-$ & 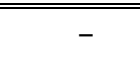 \\
\hline Eat and drink & $\$-$ & $\$-$ & $\$-$ & - \\
\hline Amusement and recreation & $\$-$ & $\$-$ & $\$-$ & - \\
\hline Retail & $\$ 0.06$ & $\$ 0.03$ & $\$ 0.05$ & 1.34 \\
\hline Wholesale & $\$ 0.01$ & $\$ 0.00$ & $\$ 0.00$ & 0.10 \\
\hline Other services & $\$ 0.70$ & $\$ 0.05$ & $\$ 0.08$ & 4.03 \\
\hline Groceries & $\$-$ & $\$-$ & $\$-$ & - \\
\hline Sporting goods & $\$-$ & $\$-$ & $\$-$ & - \\
\hline Other manufacturing & $\$ 0.15$ & $\$ 0.03$ & $\$ 0.04$ & 1.65 \\
\hline Government & $\$ 0.00$ & $\$ 0.00$ & $\$ 0.00$ & 0.00 \\
\hline Total & $\$ 0.92$ & $\$ 0.12$ & $\$ 0.17$ & 7.13 \\
\hline \multicolumn{5}{|c|}{ Total Effects } \\
\hline Sector & Sales (\$MM) & Income (\$MM) & $\begin{array}{l}\text { Value Added } \\
\text { (\$MM) }\end{array}$ & Jobs \\
\hline Lodging & $\$ 0.00$ & $\$ 0.00$ & $\$ \$ \$ 0.00$ & 0.10 \\
\hline Eat and drink & $\$ 0.01$ & $\$ 0.00$ & $\$ 0.00$ & 0.31 \\
\hline Amusement and recreation & $\$ 0.00$ & $\$ 0.00$ & $\$ 0.00$ & 0.10 \\
\hline Retail & $\$ 0.08$ & $\$ 0.04$ & $\$ 0.06$ & 1.86 \\
\hline Wholesale & $\$ 0.02$ & $\$ 0.01$ & $\$ 0.01$ & 0.31 \\
\hline Other services & $\$ 0.96$ & $\$ 0.13$ & $\$ 0.21$ & 7.44 \\
\hline Groceries & $\$ 0.00$ & $\$ 0.00$ & $\$ 0.00$ & 0.00 \\
\hline Sporting goods & $\$ 0.00$ & $\$ 0.00$ & $\$ 0.00$ & 0.00 \\
\hline Other manufacturing & $\$ 0.19$ & $\$ 0.04$ & $\$ 0.05$ & 1.96 \\
\hline Government & $\$ 0.02$ & $\$ 0.00$ & $\$ 0.01$ & 0.10 \\
\hline Total & $\$ 1.28$ & $\$ 0.23$ & $\$ 0.35$ & 12.19 \\
\hline
\end{tabular}


The sales multiplier for the region is 1.39 , meaning that an additional $\$ 0.39$ in sales is generated through secondary effects for every dollar of direct sales. Secondary effects generate an additional 5 jobs, for a total of 12 direct and secondary jobs (Table 16). Likewise, secondary effects generate an additional $\$ 110,000$ in personal income and $\$ 180,000$ in value added (personal income + proprietor's income + indirect business tax). Roughly 6 direct jobs are supported by each million dollars in total slip renter spending for new boats and annual services. Including multiplier effects, each million dollars in total slip renter spending supports about 11 jobs.

\section{Value of 1999 impacts in 2004 dollars}

The 1999 economic impacts reported above were adjusted to 2004 impacts by multiplying 1999 figures by an average consumer price index of 1.21 (U.S. Department of Labor 2006). The results are presented in Table 17.

Table 17. Regional economic impacts of Truman Lake Marina slip renters'/users' trip and renters' annual spending (in 2004 dollars, for spending within 30 miles only).

\begin{tabular}{||l|c|c|c|c||}
\hline & \multicolumn{2}{|c|}{$\begin{array}{c}\text { Trip Spending (within } \\
\text { 30 miles) }\end{array}$} & \multicolumn{2}{c|}{$\begin{array}{c}\text { Durable Goods and other } \\
\text { Annual Costs Spent Locally }\end{array}$} \\
\hline \hline Total spending (\$MM) & \multicolumn{2}{|c|}{$\$ 4.62$} & \multicolumn{2}{c||}{$\$ 1.39$} \\
\hline \hline & Direct Effects & Total Effects & Direct Effects & Total Effects \\
\hline \hline Output/sales (\$MM) & $\$ 2.91$ & $\$ 4.21$ & $\$ 1.11$ & $\$ 1.55$ \\
\hline Total income (\$MM) & $\$ 0.96$ & $\$ 1.36$ & $\$ 0.14$ & $\$ 0.27$ \\
\hline Total value added (\$MM) & $\$ 1.45$ & $\$ 2.16$ & $\$ 0.20$ & $\$ 0.42$ \\
\hline \hline $\begin{array}{l}\text { Note: Spending and economic effects in this table are in 2004 dollars, as opposed to the 1999 dollars re- } \\
\text { ported elsewhere in this report. }\end{array}$
\end{tabular}

In 2004 dollars, total marina slip user trip spending locally of $\$ 4.6$ million resulted in $\$ 1$ million in the region in personal income and $\$ 1.5$ million in value added (personal income + proprietor's income + indirect business tax).With secondary (multiplier) effects, total impacts locally were $\$ 1.4$ million in personal income and $\$ 2.2$ million in value added. There is no change to the number of direct jobs (65) in going from Tables 15 and 16 to Table 17. This is because no new expenditures by slip users are being estimated in Table 17. Instead, expenditures from the 1999 survey are being inflated to 2004 dollars. Since there are no new expenditures, there are no additional jobs being created in 2004 . 
After converting annual goods and services to 2004 dollars, the results are $\$ 1.4$ million marina slip renter spending on new boats, storage fees, insurance, and repairs/maintenance. The impacts of annual spending include $\$ 140,000$ in personal income and $\$ 200,000$ in value added. With secondary (multiplier) effects, total impacts locally were $\$ 270,000$ in personal income and $\$ 420,000$ in value added. 


\section{Study Limitations and Error}

The accuracy of the estimates in this report rests on the three inputs: visits, spending averages, and multipliers. The number of trips reported by the sample of marina slip renters and the occupancy rates of the marinas are likely the largest potential sources of error.

The multipliers and economic ratios used to convert spending to jobs and income and to estimate secondary effects come from an IMPLAN model for the four-county region. Although it is difficult to estimate the levels of error, multipliers can vary by about 10 percent between different modeling systems. Multipliers largely influence estimates of secondary effects.

Depending on the direction and magnitude of errors in visits, spending, and multipliers, the different errors may compound or cancel each other. The most important potential errors are in the estimates of total trips. As the model is linear, doubling the amount of visitation will double spending and economic impacts.

In addition to these issues, there are also conceptual issues regarding how much and which spending may be claimed by the project. It is not simple to determine if marina slip users would spend their money elsewhere if marinas were not available at Truman Lake. Furthermore, local visitors are usually excluded in estimating economic impacts, but have been included here. Since they are not a distinct segment, their contribution to the total effects is not readily estimated. However, 44 percent of the slip renters interviewed stated that their permanent residences were within 30 miles of the project. Since 82 percent of total trip spending occurred within 30 miles of the project, the impact of local spending cannot be ignored.

Only new boat purchases within 30 miles of the project are counted in this analysis. Further, it is assumed that slip rental fees and storage fees go primarily to local businesses. However, slip renters were not asked to identify the locations of their insurance companies or boat repair shops. Thus, the extent to which these expenditures accrue to the local economy is not known, but they have been counted as occurring locally (within fourcounty region). 


\section{Summary and Discussion}

Marina slip users at Truman Lake spent $\$ 3.8(\$ 4.6)^{1}$ million in triprelated expenditures and $\$ 1.2(\$ 1.4)$ million in purchases of new boats and annual services within 30 miles of the lake in 1999. Combining both triprelated and durable expenditures, the direct economic effects of slip user spending were \$3.3 (\$4)million in sales, \$0.9 (\$1.1) million in personal income, \$1.4 (\$1.7) million in direct value added, and 65 jobs. With multiplier effects, created by the recirculation of the money spent by slip users, visitor spending generated a total (direct + secondary) of $\$ 4.8(\$ 5.8)$ million in local sales, and an associated $\$ 1.4(\$ 1.6)$ million in personal income, \$2.1 (\$2.6) million in value added, and 86 jobs. Sectors receiving the greatest benefit from marina slip users were 'other services,' retail trade, food and drink, and other manufacturing. The \$3.3 million in direct sales is about 2 percent of the total of all tourism activity ( $\$ 161$ million) (sales have been price inflated for this computation).

Total economic impacts (Tables 15, 16, and 17) are useful for accountability purposes, lake support, and explaining the role of the lake in the region's economy. The REAS model results can also be used to evaluate management alternatives and strategies and to conduct sensitivity analyses. The marginal economic impacts of particular visitor segments are useful for evaluating particular actions. Table 18 shows the changes in sales, jobs, income and valued added associated with an increase or decrease of 1,00o additional party-trips by each segment. Marginal impact analysis provides answers to the question: "What if?" (reference Foreword).

For example, to evaluate the regional economic impacts of adding an additional 34 marina slips, first compute the change in party trips - 10 slips produce 300 party trips (average of 30 trips per slip per year from Table 3 ). That means 34 slips would produce about 1,000 extra party trips per year. Applying the marginal impacts for the overnight segment in Table 9, the expansion generates an additional $\$ 255,000$ in total trip spending (\$255 per party trip from Table 9 times 1,000), \$160,000 dollars in direct sales in the region, $\$ 53,000$ in personal income, $\$ 80,000$ in value added and 3.9 jobs in direct effects (computed from ratios in Table 15). In 2004 dollars, the extra 1,00o party trips per year by marina slip users would re-

\footnotetext{
${ }^{1}$ Numbers in parentheses are in 2004 dollars (See Table 17).
} 
sult in $\$ 194,000$ in direct sales in the region and $\$ 64,000$ in direct personal income. ${ }^{1}$ The impact of this alternative could be compared to others.

Table 18. Direct impacts of an additional 1,000 marina slip renter party trips by segment, Truman Lake.

\begin{tabular}{|c|c|c|c|c|c|}
\hline \multirow[b]{2}{*}{ Segments } & \multicolumn{2}{|c|}{ Local } & \multirow{2}{*}{$\begin{array}{c}\text { Personal } \\
\text { Income } \\
(\$)\end{array}$} & \multirow{2}{*}{$\begin{array}{c}\text { Value } \\
\text { Added } \\
(\$)\end{array}$} & \multirow[b]{2}{*}{ Jobs } \\
\hline & Spending (\$) & Direct Sales (\$) & & & \\
\hline \multicolumn{6}{|c|}{ (marginal impacts per 1,000 party-trips, in 1999 dollars) } \\
\hline Day use & $\$ 68,853$ & $\$ 43,283$ & $\$ 14,253$ & $\$ 21,571$ & 1.0 \\
\hline Overnight stay & $\$ 254,545$ & $\$ 160,012$ & $\$ 52,693$ & $\$ 79,746$ & 3.9 \\
\hline Small boat & $\$ 137,471$ & $\$ 86,417$ & $\$ 28,458$ & $\$ 43,068$ & 2.1 \\
\hline Medium boat & $\$ 159,096$ & $\$ 100,011$ & $\$ 32,934$ & $\$ 49,843$ & 2.4 \\
\hline Large boat & $\$ 284,444$ & $\$ 178,808$ & $\$ 58,882$ & $\$ 89,113$ & 4.3 \\
\hline \multicolumn{6}{|c|}{ (marginal impacts per 1,000 party-trips, in 2004 dollars) } \\
\hline Day use & $\$ 83,313$ & $\$ 52,372$ & $\$ 17,246$ & $\$ 26,101$ & 1.0 \\
\hline Overnight stay & $\$ 307,999$ & $\$ 193,615$ & $\$ 63,758$ & $\$ 96,493$ & 3.9 \\
\hline Small boat & $\$ 166,340$ & $\$ 104,565$ & $\$ 34,434$ & $\$ 52,112$ & 2.1 \\
\hline Medium boat & $\$ 192,506$ & $\$ 121,013$ & $\$ 39,850$ & $\$ 60,310$ & 2.4 \\
\hline Large boat & $\$ 344,178$ & $\$ 216,358$ & $\$ 71,247$ & $\$ 107,827$ & 4.3 \\
\hline
\end{tabular}

The economic impacts presented in this report document the economic significance of 24,659 marina slip user trips at Truman Lake in 1999. The impacts will vary from year to year with changes in prices, visitor volumes, the mix of visitors attracted, and other changes in the lake and surrounding communities. The REAS model has built-in procedures to price adjust spending averages over time, as we have done in this report. Updated figures may be obtained fairly easily, if there are not significant changes in visitor use and spending patterns. In the absence of significant structural changes in the local economy, multipliers will be quite stable. The primary input for updating the estimates is visitation, which must take into account any changes in the mix of visitors or their length of stay in the area.

\footnotetext{
1 The number of jobs, 3.9, remains the same in 2004 because Table 18 reflects the marginal impacts of 1,000 additional party trips; since the ratio between sales and jobs remains the same between 1999 and 2004 , the number of jobs per 1,000 additional party trips does not change.
} 


\section{References}

Chang, W. H., D. B. Propst, D. J. Stynes, and R. S. Jackson. 2003. Recreation visitor spending profiles and economic benefit to Corps of Engineers $(C E)$ projects. ERDC/EL TR-03-21. Vicksburg, MS: U.S. Army Engineer Research and Development Center.

Chang, W. H., D. J. Stynes, R. S. Jackson, and D. B. Propst. 2001. U.S. Army Corps of Engineers Recreation Economic Assessment System (REAS). Portland, OR: Poster presentation at National Natural Resources Management Conference, 2001.

Institute for Water Resources (IWR). 2006. OMB approved surveys. IWR Website. Stuart Davis, Subject Matter Expert, IWR, http://www.waterresources.us/inside/products/pub/surveyssearch.cfm?topic=Recreation (accessed July 10, 2006).

Minnesota IMPLAN Group, Inc. 1996. IMPLAN professional social accounting \$ impact analysis software: User's guide. Stillwater, MN: Minnesota IMPLAN Group, Inc.

Minnesota IMPLAN Group. 2000. IMPLAN professional software, analysis and data guide. 2nd ed., Stillwater, MN: Minnesota IMPLAN Group, Inc.

Missouri Economic Research and Information Center (MERIC), 2004. West Central Region. http://missourieconomy.org/researchandplanning/regional/westcentral/index.stm , accessed 11/10/2004.

Propst, D. B., D. J. Stynes, W. H. Chang, and R. S. Jackson. 1998. Estimating the local economic impacts of recreation at Corps of Engineers projects - 1996. Technical Report R-98-1. Vicksburg, MS: U.S. Army Engineer Waterways Experiment Station.

U.S. Army Corps of Engineers. 2006a. Economic impact analysis. Natural Resources Management Gateway, Wen-Huei Chang, Subject Matter Expert, CEERD-EE-E, www.CorpsLakes.us/REAS (accessed July 10, 2006).

U.S. Army Corps of Engineers. 2006b. Harry S. Truman Dam \& Reservoir, http://www.nwk. usace.army.mil/harryst/hst home.htm (accessed July 10, 2006).

U.S. Army Corps of Engineers. 2006c. Natural Resources Management System (NRMS) historical data. Natural Resources Management Gateway, Mike Owen, Subject Matter Expert, CESWF-OD-R. http://CorpsLakes.usace.army.mil/employees/nrms/nrms.html (accessed July 10, 2006).

U.S. Census Bureau. 2006. State and County Quickfacts, http://quickfacts.census.gov/qfd/index.html (accessed April 25, 2006).

U.S. Department of Labor. 2006. Bureau of Labor Statistics, average from 1999-2004, http://stats.bls.gov (accessed April 25, 2006). 


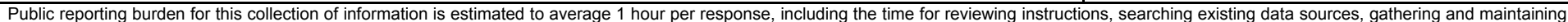

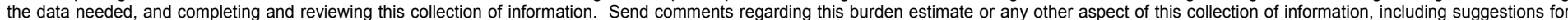

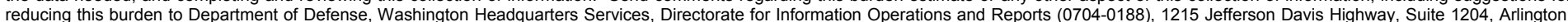

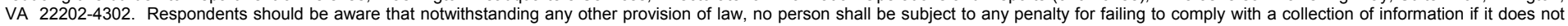
display a currently valid OMB control number. PLEASE DO NOT RETURN YOUR FORM TO THE ABOVE ADDRESS.

\begin{tabular}{l|c}
$\begin{array}{l}\text { 1. REPORT DATE (DD-MM-YYYY) } \\
\text { February 2008 }\end{array}$ & $\begin{array}{c}\text { 2. REPORT TYPE } \\
\text { Final report }\end{array}$ \\
\hline
\end{tabular}

\section{TITLE AND SUBTITLE}

Economic Impacts from Spending by Marina Slip Renters at Harry S. Truman Dam and Reservoir

\section{AUTHOR(S)}

Dennis B. Propst, Benoni L. Amsden, Wen-Huei Chang, Richard Kasul, LiChu Lee, and Kathleen Perales

\section{PERFORMING ORGANIZATION NAME(S) AND ADDRESS(ES)}

U.S. Army Engineer Research and Development Center, Environmental Laboratory, 3909 Halls Ferry Road, Vicksburg, MS 39180-6199;

Michigan State University, 115 Natural Resources Building, East Lansing, MI 48824

9. SPONSORING / MONITORING AGENCY NAME(S) AND ADDRESS(ES)

3. DATES COVERED (From - To)

5a. CONTRACT NUMBER

5b. GRANT NUMBER

5c. PROGRAM ELEMENT NUMBER

5d. PROJECT NUMBER

5e. TASK NUMBER

5f. WORK UNIT NUMBER

8. PERFORMING ORGANIZATION REPORT NUMBER

ERDC/EL TR-08-7

10. SPONSOR/MONITOR'S ACRONYM(S)

11. SPONSOR/MONITOR'S REPORT NUMBER(S)

\section{DISTRIBUTION / AVAILABILITY STATEMENT}

Approved for public release; distribution is unlimited.

\section{SUPPLEMENTARY NOTES}

\section{ABSTRACT}

This report documents the local economic impacts of marina slip users at Harry S. Truman Dam and Reservoir, located in west-central Missouri. This economic assessment is based on the results of a 1999 survey of a sample of Harry S. Truman Dam and Reservoir marina slip renters. Spending estimates are adjusted to 2004 dollars. The economic impacts estimated for Harry S. Truman Dam and Reservoir are useful for accountability purposes, lake support, and explaining the role of the lake in the region's economy. This report demonstrates how the survey results can also be used to evaluate management alternatives and strategies and to conduct sensitivity analyses.

\section{SUBJECT TERMS}

Marina slip renters

Marina slips

16. SECURITY CLASSIFICATION OF:

\section{a. REPORT}

UNCLASSIFIED

b. ABSTRACT
UNCLASSIFIED

Economic assessment

Harry S. Truman Dam and Reservoir

\begin{tabular}{|l|c|l|}
$\begin{array}{l}\text { 17. LIMITATION } \\
\text { OF ABSTRACT }\end{array}$ & $\begin{array}{l}\text { 18. NUMBER } \\
\text { OF PAGES }\end{array}$ & $\begin{array}{l}\text { 19a. NAME OF RESPONSIBLE } \\
\text { PERSON }\end{array}$ \\
\cline { 3 - 3 } & 48 & $\begin{array}{l}\text { 19b. TELEPHONE NUMBER (include } \\
\text { area code) }\end{array}$ \\
& &
\end{tabular}

